\title{
BREAKING THE STABILITY PACT: WAS IT PREDICTABLE?
}

\author{
Luigi Bonatti
}

Annalisa Cristini 
The Discussion Paper series provides a means for circulating preliminary research results by staff of or visitors to the Department. Its purpose is to stimulate discussion prior to the publication of papers.

Requests for copies of Discussion Papers and address changes should be sent to:

Dott. Stefano Comino

Dipartimento di Economia

Università degli Studi

Via Inama 5

38100 TRENTO ITALIA 
Luigi Bonatti* and Annalisa Cristini**

\title{
Breaking the Stability Pact: Was it Predictable?
}

\begin{abstract}
$\underline{\text { Abstract }}$
We show analytically that the credibility problem which has affected the European Stability Pact originates from the insufficient distinction between two reasons for having binding fiscal constraints. The first reason deals with the governments' tendency to neglect the effects of their fiscal policy on foreign governments (fiscal free-riding). The second reason follows from the governments' tendency to raise debt by lowering taxes or increasing expenditures, and then to leave it to their successors (fiscal short-termism). An enforcement mechanism relying on governments' collusion works if the fiscal constraints are not calibrated for curing fiscal short-termism but only for preventing fiscal free-riding.
\end{abstract}

Keywords: fiscal policy, policy coordination, capital formation, free-riding, short-termism.

JEL Classification numbers: E6, H3, H7, O4.

\footnotetext{
* University of Trento

** University of Bergamo
}

Email: luigi.bonatti@unibg.it; annalisa.cristini@unibg.it 
"You can't set the fox to guard the hen-house"

\section{INTRODUCTION}

On November 25, 2003, the Economic and Financial Affairs Council (ECOFIN) decided "not to act on the basis of the Commission Recommendations" and agreed "to hold the Excessive Deficit Procedure for Germany and France in abeyance". The European Commission "deeply regretted that the Council had not followed the spirit and the rules of the Treaty and the Stability and Growth Pact (SGP) that were agreed unanimously by all Member States" and underlined that "only a rule-based system can guarantee that commitments are enforced and that all Member States are treated equally". The European Court of Justice annulled the decisions of the ECOFIN Council, although confirming that the latter has the right to exercise discretion in the implementation of the Excessive Deficit Procedure. On March 20, 2005, ECOFIN adopted a report on "improving the implementation of the SGP", which was subsequently endorsed by the European Council. This report now forms part of the SGP. This reform makes the surveillance of budgetary positions more adaptable to country-specific circumstances, allowing each member state to present a country-specific medium-term objective which may diverge from the close to balance or in surplus requirement which was prescribed by the original SGP. Moreover, the reform introduces more flexibility and discretion in subjecting governments to the excessive deficit procedure and in requiring corrective actions. The reform was unanimously perceived as the confirming evidence that most European governments were not willing to comply with the severe fiscal discipline imposed by the original SGP. ${ }^{1}$

This sequence of events demonstrated what several critics had envisaged, i.e. that the Pact lacked credibility because the institutional design of its enforcement mechanism was inconsistent with the aims that it intended to pursue. The present paper focuses on this point and leaves aside other issues that were recently raised, going from the alleged insufficient room conceded by the Pact to the working of automatic stabilizers and discretionary fiscal policies to the opportunity of changing the budget indicators targeted by the Pact. In this way, the value added of our paper amounts to showing analytically that at the root of the SGP's credibility problem there is the insufficient awareness that the governments' attitudes towards the SGP

\footnotetext{
${ }^{1}$ In particular, the European Central Bank expressed immediately its deep concern about the effects of the reform: "The Governing Council of the ECB is seriously concerned about the proposed changes to the Stability and Growth Pact" (Statement of the Governing Council of 21 March 2005).
} 
reflect the two different reasons that justify the need of binding fiscal constraints in such a context. The first reason has to do with the temptation of any single national government to free riding, namely to deciding its fiscal policy irrespectively of its implications for the foreign governments. The second reason deals with the inevitable short-termism of elected governments to which it appears attractive to lower taxes or increase expenditures by raising debt, and then leave it to their successors. If fiscal constraints are calibrated so as to internalize the negative externalities that issuing too much debt generates on foreign governments, an enforcement mechanism depending on the collective willingness of the governments to sanction defiant behavior can work: cooperative behavior on the part of any single fiscal authority is in the common interest of all governments. In contrast, if fiscal constraints are set so as to implement in all member states a fiscal policy that is optimal from a long-term point of view, one cannot leave the enforcement of such constraints to the representatives of the member governments (the ECOFIN): sharing a short-term perspective, national governments would collude to elude these fiscal constraints. The conclusion is that the provisions of the SGP are consistent with the objective of enforcing cooperative behavior among national governments, but not with the additional objective of having all member countries caring of the long-term welfare effects of current fiscal policies. This more ambitious objective would require that the authority enforcing the respect of the fiscal constraints be independent-as the European Central Bank (ECB)—of the national governments.

The analysis is conducted within an overlapping generations (OLG) framework, where national governments are concerned about the welfare of the living (and voting!) generations only and finance the provision of a public good entering the households' utility function by taxing the households' labor income and assets' gross returns, and by raising debt. In the presence of internationally integrated markets, national fiscal policies determine spillovers affecting the welfare of the households living in other countries. This creates a situation of interdependence among national fiscal policies, that we model as a n-governments dynamic game. We derive the Nash-Cournot (subgame-perfect) equilibrium path of the game in which each national government acts non-cooperatively and compare it to the path emerging when national governments 
act cooperatively. ${ }^{2}$ All governments are better off under cooperation: it is in their collective interest to enforce cooperative behavior. It is beyond the scope of this paper to elaborate on the design of an appropriate mechanism for the enforcement of intergovernmental cooperation, since our objective is to demonstrate that --while it is in the interest of short-sighted national governments to enforce a "Pact" that prevents some government from damaging the other governments--it is not in their interests to enforce a "Pact" that prevents some government from damaging the future generations. Indeed, we derive the path emerging if a benevolent planner, caring also of the future generations' welfare, could decide both current and future fiscal policies, and we show that short-sighted national governments would never enforce a "Pact" dictating such fiscal policies.

The paper is organised as follows: section 2 motivates the model structure in the light of the relevant literature; section 3 presents the model; section 4 characterizes the equilibrium paths emerging under authorities' short-termism; section 5 characterizes the equilibrium path emerging when a benevolent planner cares also about the future generations' welfare; section 6 concludes.

\section{MOTIVATIONS AND RELEVANT LITERATURE}

It has been noted that fiscal rules may act both as disciplinary and coordinating devices (see PisaniFerry, 2002) and that these two aspects are closely intertwined in the SGP (see Allsopp and Artis, 2003). However, no other formal analysis—-to our knowledge-focuses on how this duplicity can originate the serious credibility problem which affects the SGP.

In assessing the reasons for having binding fiscal rules in the European Monetary Union (EMU), the ECB has recently stated: "The main rationale for constraining fiscal policies via rules lies in the temptation for governments to spend more than they can afford and pass the burden onto future taxpayers. If unchecked, this results in a deficit bias where high deficits lead to growing debt levels that can cast a permanent shadow over economic prospects. High deficits and debt result in higher long-term interest rates and lower private investment as they compete for private savings. This can lead to a permanent loss of output over the long

\footnotetext{
${ }^{2}$ It is apparent that the path emerging under cooperation coincides with the path that would be selected by an elected federal authority with control on the fiscal policy of the entire area.
} 
run" (ECB, 2005, p. 65). Economic theory has explained the need of imposing disciplinary constraints to the governments' discretionary powers in fiscal policy by emphasizing the political distortions that generate excessive accumulation of public debt. These distortions come from the short-term bias that affects politicians because of their desire to please their constituency before elections or to impose heavy burdens to their successors, or because of their awareness that they may not be in office when the benefits of their fiscal restraint will be enjoyed (e.g. Nordhaus, 1975; Persson and Svensson, 1989; Alesina and Tabellini, 1990; Gersbach, 1998). Obviously, this short-termism makes sense only in a world where the Barro-Ricardo equivalence does not hold, namely in a world where private agents have finite lives and do not fully care about the well-being of their descendants, or are bequest constrained, or suffer from incomplete information or from bounded rationality (thus being subject to "fiscal illusion") (e.g. Blanchard, 1985; Cukierman and Meltzer, 1989; Persson and Tabellini, 1990; Buti and van den Noord, 2003).

In this context, the function of binding fiscal rules is to prevent politicians from an excessive use of the public debt aimed at reducing the burden of taxation in the present by redistributing it over time and across generations. Therefore, this function related to the intertemporal dimension of fiscal policy exists independently of the possible presence of inter-country spillovers. In principle, each country could implement its own institutional arrangements in order to overcome the deficit bias inherent in the political process. ${ }^{3}$ As an application of the principle of subsidiarity, there is no need that rules designed for protecting the citizens of a country from the long-term costs of fiscal misbehaviour by their elected politicians be managed at the supra-national level (see Allsopp and Artis, 2003). However, it was argued that the constraints of the SGP have been seen--especially by those countries with a history of persistently high public deficit and more in need of fiscal consolidation--as an external disciplinary device that could help controlling the internal pressures toward a more loose fiscal stance (see Allsopp and Vines, 1998). As a

${ }^{3}$ Different institutional arrangements can be conducive to fiscal discipline, depending on the specific electoral system and government structure of a country: binding budgetary guidelines ("contact approach") tend to be applied in countries with party fragmentation and coalition governments, while the concentration of fiscal powers in the hands of a "strong" minister ("delegation approach") is employed in countries with majority governments (see Hallerberg et al., 2004). 
matter of fact, this use of the EU's authority to protect the European citizens from the short-term bias of their own national policy makers is not in keeping with the institutional design of the SGP, according to which national governments "are supposed to apply the rules to themselves, thereby having incentives for collusion and horse-trading" (Buti et al., 2003, p. 106). If this is the case, the ceilings dictated by the Pact are bound to be time inconsistent: the fiscal deficits of short-sighted governments will systematically exceed them.

In modeling the inevitable tension between the short-term objectives of elected governments and the long-term welfare implications of fiscal policy, we adopt an OLG set-up without bequests, which allows us to define precisely what is the optimal sequence of the debt-to-GDP ratio dictated by a benevolent planner caring also about the well-being of the future generations, and to contrast it with the fiscal policies decided by short-sighted governments. Hence, the planned sequence of deficit targets consistent with the optimal path implemented by the benevolent planner should be considered a reasonable approximation of those fiscal policies conducive to strong sustainable growth which represent the stated objective of the SGP. Indeed, even if the SGP does not refer to the numerical ceilings that it dictates as "optimal" levels, these ceilings go well beyond what is needed for solvency or sustainability and are justified because of their desirable long-term implications. ${ }^{4}$ Finally--given that the analysis focuses on the long-term implications of fiscal policy--we have opted for a non-monetary framework, consistently with the hypothesis that money cannot affect real variables in the long run.

As far as the coordinating role of binding fiscal rules is concerned, this is also clearly stated by the ECB according to which: "As national financial markets become more integrated, sovereign issuers can draw on a larger and more liquid currency area-wide capital market. A government that increases its deficits will be able to finance the additional expenditure more easily because the cost of the additional borrowing in terms of higher interest rates is, at least partly, spread across the entire currency area. Consequently, the spillover effects from deficit spending in one country on other countries are also greater in EMU, making the participant Member States' fiscal policies all the more a matter of common concern” (ECB, 2005, pp.

\footnotetext{
${ }^{4}$ It is apparent that--by complying with the "close to balance or in surplus" rule dictated by the original SGP-the debt-to-GDP ratio would converge over time to zero or even to some negative number.
} 
65-66). As emphasized by Fatás and Mihov (2003), most of the literature on international policy coordination starts with the assumption that, in the absence of some arrangement enforcing cooperation among national policy makers, domestic fiscal policies are run optimally taking into consideration internal conditions, but they fail to internalize the externalities they impose on other countries. This is the case of Kehoe (1987) and Chari and Kehoe (1990, 2003), where each national government maximizes the welfare of both its current (and future residents) and imposes externalities on other countries by crowding out the world capital stock, by affecting world prices or by inducing the common central bank to raise the inflation rate. The two-period model presented by Beetsma and Uhlig (1999) moves away from a set-up where, in the absence of international coordination, domestic fiscal policies are run optimally except for their failure to internalize the externalities they cause, since it shares with our framework the point of view that governments are short-sighted. In their model, the fact that in a monetary union the accumulation of higher debt by an individual government has negative spillovers on the other member countries (since it induces the common central bank to raise the inflation rate) creates an incentive for all the governments of the union to enforce a Pact curing the distortions caused by governments' short-termism. ${ }^{5}$ However, Beetsma and Uhlig (1999) do not focus on the problems arising when the Pact to be enforced by national governments has the twofold scope of avoiding negative externalities on other governments and of offsetting the detrimental long-term effects that each short-sighted government causes on its residents. Moreover, using a two-period set-up without capital accumulation, they cannot capture the consequences on long-term growth of the fiscal policies conducted by short-sighted politicians. Similarly, the static model presented by Uhlig (2002) to analyze the interdependence among national debt policies does not treat the intertemporal tradeoffs originated by the fiscal authorities' possibility of running deficits. In contrast, Beltrametti and Bonatti (2004) is consistent with the spirit of the present paper, since it deals with the international coordination of pension policies decided by short-sighted national authorities in a context where pension policies can influence national savings and the world capital stock.

\footnotetext{
${ }^{5}$ Also Dixit and Lambertini (2001) address the complex interaction between a central bank and a number of fiscal authorities.
} 
In this paper, we are concerned with the long-term implications of current fiscal policies and focus on their impact on capital formation; in this context monetary policy is of second order importance. Moreover, it is well known that the inter-country spillovers of fiscal policies may be relevant within an integrated economic area, no matter whether the area has an unique currency. Therefore, using a simplified framework, we assume internationally integrated capital markets and allow crowding out of the world capital formation due to spillovers caused by national fiscal policies.

Turning to the evidence on capital market integration, the ECB reports that the unexplained yield variance of the EU government bond market--once common factors are taken into account--dropped from $50 \%$ in 1997 to $5 \%$ in 2000, confirming that integration rose with the common currency (ECB, 2003). The European corporate bond market also underwent significant changes: from 1998 to 2003 its outstanding value almost tripled and, most importantly, such an increase was brought about by the participation of industrial corporations whose proportion rose from $3 \%$ to almost $40 \%$. In addition, the share of assets invested in bond funds with a Europe-wide investment strategy, rose, in the international portfolio of institutional investors, from $17 \%$ in 1998 to $80 \%$ in 2003, again signalling the fostering role played by the common currency (Baele et al., 2004).

For crowding out to take place however a significant response of the real interest rate to changes in the deficit is also required. The budget deficit surge of the Bush's administration and the more flexible Pact in Europe, have spurred some additional significant literature on this topic, although it goes without saying that disentangling the debt and deficit effects from those of other factors remains a complicated matter. For the USA, Laubach (2003) estimates that one percentage point increase in the projected deficit-to-GDP ratio raises long-term interest rates by roughly 25 basis points. ${ }^{6}$ Again for the USA, Rubin et al. (2004) relay on several estimates to conclude that private savings offset about a quarter of the public saving decline and that

\footnotetext{
${ }^{6}$ The President's Council of Economic Advisers suggests that a sustained increase in the deficit equal to one percent of GDP would raise interest rates by 30 basis points. Results from some macro-econometric models, including the FRB/US model used at the Federal Reserve, shows an effect larger than 60 basis points.
} 
about one third of the decline in national saving is offset by capital inflows from abroad; the rest is reflected in a reduction in domestic investment ${ }^{7}$.

Ford and Laxton (1999), considering eight OECD countries find that the OECD-wide debt to GDP ratio and the OECD-wide government consumption to GDP ratio explain a large proportion of the variance of the national real interest rates on government bonds while the role of domestic factors is more controversial (Breedon et al. 1999). However, Perotti (2002) using a VAR model for USA, UK, Canada West Germany and Australia finds that random discretionary fiscal policy shocks have an ambiguous effect on the short term nominal and real interest rate. As Perotti admits, this ambiguity may be due to the use of the short-term real interest rate where the long term one might be more appropriate. This view is shared by Rubin et al. (2004), who further observe that in addition of using the long term interest rate, the expected budget deficit should also be taken into account since financial markets are forward-looking ${ }^{8}$.

For the European Union, Eichengreen and Wyplosz (1998) argue that the effect of a country's borrowing on the interest rates union-wide is not relevant, while Welsch (2000) finds that the spillovers of domestic fiscal policies occur mainly through the interest rate channel. Along the same line the ECB (2004) recognises the impact that a rising demand for funds due to increasing public deficits can have on the capital market and other relevant effects ascribable to the expected deficits and debts. More recently Faini (2006) using a panel of 10 EMU members for the period 1979-2002 finds evidence of significant spillover effects within the eurozone: an expansionary fiscal policy in one member country impacts more on the EMU real interest rates than on the country interest rate spread. These results confirm those of Chinn and Frenkel (2005) who show that the European long term real interest rate positively depends upon the debt ratio and the expected debt ratio. At the OECD level Ardegna at al. (2004), using a dynamic VAR on a panel of 16 countries from 1960 to 2002, find that a percentage point rise of the deficit to GDP ratio increases the long term interest rate by as much as 150 basis points after 10 years, while the public debt to GDP ratio has a

\footnotetext{
${ }^{7}$ In other words, an increase in the budget deficit of $\$ 100$ reduces national saving by about $\$ 75$, and that $\$ 75$ reduction in national saving is reflected in a $\$ 25$ increase in borrowing from abroad and a $\$ 50$ reduction in domestic investment (Rubin et al., 2004).

${ }^{8}$ According to Gale and Orszag (2003) studies incorporating expectations of future deficits tend to find economically and statistically significant connections between anticipated deficits and current interest rates.
} 
relatively minor effect and becomes positive once the debt ratio overcomes a given threshold. They also show that a deterioration of public finances abroad negatively affects the national interest rates thus confirming that the OECD financial markets are sufficiently integrated.

\section{THE MODEL}

We consider an international economy comprising $\mathrm{n} \geq 2$ national economies in discrete time over an infinite time horizon. In each country i, i=1,2,..,n, there are identical individuals and firms; for simplicity and without loss of generality, it is assumed that the structural parameters and the initial conditions of the $\mathrm{n}$ countries are equal. Agents' expectations are consistent with the actual processes followed by the relevant variables ("perfect foresight").

\section{Individuals}

Individuals live for two periods, so that in each period t the country i population consists of two generations, the old and the young. For simplicity and without loss of generality, it is assumed that country i population remains constant. Moreover, the large number of individuals in each cohort living in i is normalized to unity. Finally, individuals' mobility across countries is ruled out.

Young individuals work full time, supply inelastically one unit of labor services and save a portion of their income for their old age. Old individuals do not work and live on the assets accumulated in the previous period. Both young and old individuals get utility from consuming a private good and from a public good provided by the government, which finances its provision by taxing individuals' income.

Thus, the period $t$ budget constraint of a member of the young generation is:

$$
\left(1-\tau_{\mathrm{it}}^{\mathrm{y}}\right) \mathrm{W}_{\mathrm{it}} \geq \mathrm{C}_{\mathrm{it}}^{\mathrm{y}}+\mathrm{S}_{\mathrm{it}}
$$

where $\tau_{\mathrm{it}}^{\mathrm{y}}$ is the tax rate on labor income, $\mathrm{W}_{\mathrm{it}}$ is the wage rate, $\mathrm{C}_{\mathrm{it}}^{\mathrm{y}}$ is the amount of private good consumed by a young individual and $\mathrm{S}_{\mathrm{it}}$ are the savings (accumulated assets) of a young individual.

The period t budget constraint of an old individual is:

$$
\left(1-\tau_{\mathrm{it}}^{\mathrm{o}}\right)\left(1+\mathrm{r}_{\mathrm{t}}\right) \mathrm{S}_{\mathrm{it}-1} \geq \mathrm{C}_{\mathrm{it}}^{\mathrm{o}},
$$


where $\tau_{\text {it }}^{\mathrm{o}}$ is the tax rate on the gross return on assets, $\mathrm{r}_{\mathrm{t}}$ is the "world" market (net) rate of return on assets and $\mathrm{C}_{\mathrm{it}}^{\mathrm{o}}$ is the amount of private good consumed by an old individual.

The lifetime utility of a young individual located in country $i$ is assumed to be given by

$$
\mathrm{u}_{\mathrm{it}}^{\mathrm{y}}=\ln \left(\mathrm{C}_{\mathrm{it}}^{\mathrm{y}}\right)+\gamma \ln \left(\mathrm{G}_{\mathrm{it}}\right)+\theta\left[\ln \left(\mathrm{C}_{\mathrm{it}+1}^{\mathrm{o}}\right)+\gamma \ln \left(\mathrm{G}_{\mathrm{it}+1}\right)\right], \gamma>0,0<\theta \leq 1
$$

where $G_{i t}$ is the public good and $\theta$ is a time-preference parameter. Note that individuals have no altruistic motivation in favor of their children. Thus, a young individual solves $\underset{\mathrm{C}_{\mathrm{it}}^{\mathrm{y}}, \mathrm{C}_{\mathrm{it}+1}^{\mathrm{o}}}{\mathrm{Max}} \mathrm{u}_{\mathrm{it}}^{\mathrm{y}}$, subject to (1) and (2).

Consistently with (3a), the utility of an old individual located in country $i$ is given by

$$
u_{i t}^{o}=\ln \left(C_{i t}^{o}\right)+\gamma l n\left(G_{i t}\right) .
$$

Firms

Firms act competitively. The large number of firms operating in country $i$ is normalized to unity. All firms produce a single product according to the constant-returns-to-scale technology:

$$
\mathrm{Q}_{\mathrm{it}}=\mathrm{L}_{\mathrm{it}}^{\alpha} \mathrm{K}_{\mathrm{it}}^{1-\alpha}, 0<\alpha<1,
$$

where $\mathrm{Q}_{\mathrm{it}}$ is the output of country $\mathrm{i}$ in period $\mathrm{t}, \mathrm{L}_{\mathrm{it}}$ is labor employed in country $\mathrm{i}$, and $\mathrm{K}_{\mathrm{it}}$ is physical capital rent by firms of country $i$. In each $t$, the representative firm located in $\mathrm{i}$ chooses $\mathrm{L}_{\mathrm{it}}$ and $\mathrm{K}_{\mathrm{it}}$ so as to maximize its profits:

$$
\max _{\mathrm{L}_{\mathrm{it}}, \mathrm{K}_{\mathrm{it}}} \mathrm{L}_{\mathrm{it}}^{\alpha} \mathrm{K}_{\mathrm{it}}^{1-\alpha}-\mathrm{W}_{\mathrm{it}} \mathrm{L}_{\mathrm{it}}-\mathrm{R}_{\mathrm{it}} \mathrm{K}_{\mathrm{it}}
$$

where $R_{i t}$ is the market rental rate on capital paid by firms of $i$ in period t. Notice that the price of the unique good produced in the economy is normalized to one.

\section{Fiscal authorities' budget constraints}

In each $t$, the fiscal authority of country i must satisfy its budget constraint:

$$
\mathrm{B}_{\mathrm{it}+1}=\left(1+\mathrm{r}_{\mathrm{t}}\right) \mathrm{B}_{\mathrm{it}}+\mathrm{G}_{\mathrm{it}}-\tau_{\mathrm{it}}^{\mathrm{o}}\left(1+\mathrm{r}_{\mathrm{t}}\right) \mathrm{S}_{\mathrm{it}-1}-\tau_{\mathrm{it}}^{\mathrm{y}} \mathrm{W}_{\mathrm{it}}, \mathrm{B}_{\mathrm{i} 0} \text { and } \mathrm{S}_{\mathrm{i}-1} \text { given, }
$$

where $\mathrm{B}_{\text {it }}$ is the public debt at the beginning of period t. Moreover, each national authority must satisfy the solvency condition: 


$$
\lim _{s \rightarrow \infty} \frac{B_{i s+1}}{\prod_{v=t}^{s}\left(1+r_{v}\right)}=0
$$

Objectives of fiscal authorities caring only about the welfare of the living (and voting!) generations

In the absence of intergenerational altruism on the part of individuals, it is realistic that each national government is sensitive only to the interests of the living (and voting!) generations located in its own country. However, even if national governments are only concerned with their re-election and care only about the welfare of the living generations, young individuals are supposed to be rational and perfectly aware of the consequences of current policies' for their future well-being. Therefore, the relevant benchmark for the analysis is the case in which the entire lifetime well-being of the young generations enters the authorities' objective function together with the utility of the old cohorts. This amounts to say that in period $t$ the objective of each national government is to maximize

$$
\mathrm{U}_{\mathrm{it}}=\xi \mathrm{u}_{\mathrm{it}}^{\mathrm{o}}+(1-\xi) \mathrm{u}_{\mathrm{it}}^{\mathrm{y}}, 0<\xi<1
$$

where the parameter $\xi$ measures the weight assigned to the old cohort's utility in the social welfare function. Note that (7) implies that the old-age well-being of the generation which is young in t enters as an argument of the social welfare function both in $t$ and in $t+1$. This captures the fact that the young generation is concerned also about its future well-being and in each period a national government takes care of the concerns of both the old and the young generation.

Objectives of fiscal authorities caring also about the welfare of the future (and not yet voting!) generations

Suppose now that in each country the fiscal policy were determined taking care not only of the concerns of the living generations, but also of the interests of the not yet born generations. In this case, we model the behavior of the fiscal authority as if its objective were to maximize

$$
\sum_{\mathrm{s}=\mathrm{t}}^{\infty} \theta^{\mathrm{s}-\mathrm{t}} \mathrm{U}_{\mathrm{is}}
$$

where the authority discounts the future social welfare at the same rate at which young individuals discount their future utilities. 


\section{Market-clearing conditions}

One has equilibrium in each national labor market when the wage is such that firms desire to hire all available workers:

$$
\mathrm{L}_{\mathrm{it}}=1 \text {. }
$$

The "world" market for the single product is perfectly competitive. Assuming for simplicity that capital fully depreciates after one period, equilibrium in this market requires that

$$
\mathrm{Q}_{\mathrm{t}}=\mathrm{C}_{\mathrm{t}}^{\mathrm{y}}+\mathrm{C}_{\mathrm{t}}^{\mathrm{o}}+\mathrm{K}_{\mathrm{t}+1}
$$

where $\mathrm{C}_{\mathrm{t}}^{\mathrm{y}}=\sum_{\mathrm{i}=1}^{\mathrm{n}} \mathrm{C}_{\mathrm{it}}^{\mathrm{y}}, \mathrm{C}_{\mathrm{t}}^{\mathrm{o}}=\sum_{\mathrm{i}=1}^{\mathrm{n}} \mathrm{C}_{\mathrm{it}}^{\mathrm{o}}, \mathrm{Q}_{\mathrm{t}}=\sum_{\mathrm{i}=1}^{\mathrm{n}} \mathrm{Q}_{\mathrm{it}}, \mathrm{K}_{\mathrm{t}}=\sum_{\mathrm{i}=1}^{\mathrm{n}} \mathrm{K}_{\mathrm{it}}$ and $\mathrm{K}_{0}$ given.

Similarly, the "world" asset market is perfectly integrated. Thus, equilibrium in the "world" asset market requires that

$$
\mathrm{B}_{\mathrm{t}}+\mathrm{K}_{\mathrm{t}}=\mathrm{S}_{\mathrm{t}-1}
$$

where $B_{t}=\sum_{i=1}^{n} B_{i t}$ and $S_{t}=\sum_{i=1}^{n} S_{i t}$.

Given that capital is perfectly mobile, (11) implies that

$$
\mathrm{R}_{\mathrm{it}}=1+\mathrm{r}_{\mathrm{t}} \text {. }
$$

Private sector equilibrium as a function of the tax rates

Optimizing behavior on the part of individuals implies:

$$
\begin{gathered}
\mathrm{S}_{\mathrm{it}}=\frac{\theta \mathrm{W}_{\mathrm{it}}\left(1-\tau_{\mathrm{it}}^{\mathrm{y}}\right)}{1+\theta}, \\
\mathrm{C}_{\mathrm{it}}^{\mathrm{y}}=\mathrm{W}_{\mathrm{it}}\left(1-\tau_{\mathrm{it}}^{\mathrm{y}}\right)-\mathrm{S}_{\mathrm{it}}=\frac{\mathrm{W}_{\mathrm{it}}\left(1-\tau_{\mathrm{it}}^{\mathrm{y}}\right)}{1+\theta}, \\
\mathrm{C}_{\mathrm{it}+1}^{\mathrm{o}}=\left(1-\tau_{\mathrm{it}+1}^{\mathrm{o}}\right)\left(1+\mathrm{r}_{\mathrm{t}+1}\right) \mathrm{S}_{\mathrm{it}} .
\end{gathered}
$$

Optimizing behavior on the part of firms and equilibrium in national labor markets and in the internationally integrated capital market imply:

$$
\mathrm{W}_{\mathrm{it}}=\alpha \mathrm{K}_{\mathrm{it}}^{1-\alpha}=\alpha\left(\frac{\mathrm{K}_{\mathrm{t}}}{\mathrm{n}}\right)^{1-\alpha},
$$




$$
1+\mathrm{r}_{\mathrm{t}}=(1-\alpha) \mathrm{K}_{\mathrm{it}}^{-\alpha}=(1-\alpha)\left(\frac{\mathrm{K}_{\mathrm{t}}}{\mathrm{n}}\right)^{-\alpha} .
$$

Equations (15) and (16) imply that the "world" capital stock is evenly distributed among countries even if the countries may differ with respect to their national savings ${ }^{9}$. This is due to the fact that the ability of each country to attract capital depends only on the parameter $\alpha$ determining the capital share of national income. Since this parameter is assumed to be equal across countries, possible differences in national tax rates affect the after-tax income of households leaving unchanged the firms' labor and capital cost, which depend on $\alpha$ and on the installed stock of capital. Having the same capital stock, one can see from (15) that all countries have the same equilibrium wage. Moreover, from (11), (13) and (15) we obtain:

$$
\mathrm{K}_{\mathrm{t}+1}=\frac{\theta \alpha}{1+\theta} \sum_{\mathrm{i}=1}^{\mathrm{n}}\left(1-\tau_{\mathrm{it}}^{\mathrm{y}}\right)\left(\frac{\mathrm{K}_{\mathrm{t}}}{\mathrm{n}}\right)^{1-\alpha}-\sum_{\mathrm{i}=1}^{\mathrm{n}} \mathrm{B}_{\mathrm{it}+1} .
$$

Given (17), the change in $\mathrm{K}_{\mathrm{t}+1}$ due to a marginal increment in $\tau_{\mathrm{it}}^{\mathrm{y}}$ is:

$$
\frac{\partial \mathrm{K}_{\mathrm{t}+1}}{\partial \tau_{\mathrm{it}}^{\mathrm{y}}}=\frac{-\theta \alpha}{1+\theta}\left(\frac{\mathrm{K}_{\mathrm{t}}}{\mathrm{n}}\right)^{1-\alpha}
$$

while the change in $\mathrm{K}_{\mathrm{t}+1}$ due to a marginal increment in $\mathrm{B}_{\mathrm{it}+1}$ is:

$$
\frac{\partial \mathrm{K}_{\mathrm{t}+1}}{\partial \mathrm{B}_{\mathrm{it}+1}}=-1
$$

\section{NON-COOPERATIVE VERSUS COOPERATIVE EQUILIBRIUM UNDER AUTHORITIES' SHORT-TERMISM}

As a national government cares only about the welfare of the living generations located in its own country, it is worth to emphasize that each government has full control only on its current fiscal policy since the future governments will respond to the interest of the generations then living. Moreover, all agents are perfectly aware that the fiscal policy of each country generates externalities affecting the welfare of the individuals living in other countries. Thus, in each period, young individuals

\footnotetext{
${ }^{9}$ This possibility implies that with $r_{t}>0$ countries whose installed capital is larger than their assets accumulated in the previous period run a trade balance surplus to finance the interest payments due to foreigners.
} 
make their saving decisions knowing the current policies of the authorities and anticipating correctly nextperiod fiscal policies. In their turn, the authorities fully endogeneize the optimal reactions of private agents to their policies.

Since national fiscal policies have spillover effects affecting the welfare of foreign individuals, national fiscal policies are interdependent. Therefore, the authorities' short-termism is consistent with two alternative frameworks depending on whether fiscal policies are determined by each government in full autonomy (non-cooperative equilibrium) or by some institutional arrangement (a "Pact") permitting a credible commitment on the part of each fiscal authority to follow those policies that are determined collectively by all the governments (cooperative solution).

\section{Game among national governments}

As each national authority acts in full autonomy (without any international coordination), in every $\mathrm{t}$ it solves:

$$
\underset{\omega_{\text {it }}}{\operatorname{Max}} U_{\text {it }}
$$

where $\omega_{\mathrm{it}}=\left\{\tau_{\mathrm{it}}^{\mathrm{y}}, \mathrm{B}_{\mathrm{it}+1}, \tau_{\mathrm{it}}^{\mathrm{o}}, \mathrm{G}_{\mathrm{it}}\right\}$, subject to $(6), \mathrm{K}_{\mathrm{t}}, \mathrm{B}_{\mathrm{it}}$ and $\mathrm{S}_{\mathrm{it}-1}$ given, taking into account the optimizing behavior of private agents, taking as given the current fiscal policies of the other countries and anticipating correctly the future fiscal policies of all countries. A Nash-Cournot (subgame-perfect) equilibrium path of this game among national authorities is characterized by a n-tuple of sequences $\left\langle\left\{\omega_{1 \mathrm{z}}^{*}\right\}_{\mathrm{z}=\mathrm{t}}^{\infty},\left\{\omega_{2 \mathrm{z}}^{*}\right\}_{\mathrm{z}=\mathrm{t}}^{\infty}, \ldots,\left\{\omega_{\mathrm{nz}}^{*}\right\}_{\mathrm{z}=\mathrm{t}}^{\infty}\right\rangle$ such that each $\omega_{\mathrm{it}}^{*}$ solves (19) given the other countries' current policies maximizing (19) and the future (Nash-Cournot) equilibrium policies of all countries.

Knowing consumption, savings, wages, interest rate and capital stock as functions of the authorities' fiscal policies, one can derive the equilibrium policy rules of the national authorities by backward induction (see the Appendix). Along the (subgame-perfect) equilibrium path, in each $\mathrm{t}$ an interior solution to the problem of the government i must satisfy the following set of conditions:

$$
\frac{-(1-\xi)}{1-\tau_{\mathrm{it}}^{\mathrm{y}}}+\frac{\theta(1-\xi)(1-\alpha)(1+\gamma)}{\mathrm{K}_{\mathrm{t}+1}} \frac{\partial \mathrm{K}_{\mathrm{t}+1}}{\partial \tau_{\mathrm{it}}^{\mathrm{y}}}+\lambda_{\mathrm{i}} \alpha\left(\frac{\mathrm{K}_{\mathrm{t}}}{\mathrm{n}}\right)^{1-\alpha}=0, \quad \mathrm{i}=1,2, \ldots, \mathrm{n},
$$




$$
\begin{gathered}
\frac{\theta(1-\xi)(1-\alpha)(1+\gamma)}{\mathrm{K}_{\mathrm{t}+1}} \frac{\partial \mathrm{K}_{\mathrm{t}+1}}{\partial \mathrm{B}_{\mathrm{it}+1}}+\lambda_{\mathrm{i}}=0, \mathrm{i}=1,2, \ldots, \mathrm{n}, \\
\frac{-\xi}{1-\tau_{\mathrm{it}}^{\mathrm{o}}}+\lambda_{\mathrm{i}} \mathrm{S}_{\mathrm{it}-1}(1-\alpha)\left(\frac{\mathrm{K}_{\mathrm{t}}}{\mathrm{n}}\right)^{-\alpha}=0, \mathrm{i}=1,2, \ldots, \mathrm{n}, \\
\frac{\gamma}{\mathrm{G}_{\mathrm{it}}}-\lambda_{\mathrm{i}}=0, \mathrm{i}=1,2, \ldots, \mathrm{n}, \\
\mathrm{B}_{\mathrm{it}+1}-(1-\alpha)\left(\frac{\mathrm{K}_{\mathrm{t}}}{\mathrm{n}}\right)^{-\alpha} \mathrm{B}_{\mathrm{it}}-\mathrm{G}_{\mathrm{it}}+\tau_{\mathrm{it}}^{\mathrm{o}} \mathrm{S}_{\mathrm{it}-1}(1-\alpha)\left(\frac{\mathrm{K}_{\mathrm{t}}}{\mathrm{n}}\right)^{-\alpha}+\tau_{\mathrm{it}}^{\mathrm{y}} \alpha\left(\frac{\mathrm{K}_{\mathrm{t}}}{\mathrm{n}}\right)^{1-\alpha}=0, \mathrm{i}=1,2, \ldots, \mathrm{n},
\end{gathered}
$$

where $\lambda_{i}$ is a Lagrange multiplier. By solving (20) and eliminating $\lambda_{i}$, one can obtain the equilibrium policy rules of the government i:

$$
\begin{aligned}
\tau_{\mathrm{it}}^{\mathrm{y}^{*}} & =\tau^{\mathrm{y}^{*}}=1-\frac{(1-\xi)(1+\theta) \mathrm{n}}{(1+\gamma) \alpha[\mathrm{n}+\theta(1-\xi)(1-\alpha)]}, \\
\mathrm{B}_{\mathrm{it}+1}^{*} & =\frac{\mathrm{B}_{\mathrm{t}+1}^{*}}{\mathrm{n}}=\frac{(1-\xi) \theta[\mathrm{n}-(1-\alpha)(1+\gamma)]}{(1+\gamma)[\mathrm{n}+\theta(1-\xi)(1-\alpha)]}\left(\frac{\mathrm{K}_{\mathrm{t}}}{\mathrm{n}}\right)^{1-\alpha} \\
\tau_{\mathrm{it}}^{\mathrm{O}^{*}} & =1-\frac{\xi \mathrm{K}_{\mathrm{t}}}{(1+\gamma)(1-\alpha)\left(\frac{\mathrm{K}_{\mathrm{t}}+\mathrm{B}_{\mathrm{t}}}{\mathrm{n}}\right)[\mathrm{n}+\theta(1-\xi)(1-\alpha)]}, \\
\mathrm{G}_{\mathrm{it}}^{*} & =\frac{\gamma(1+\gamma)[\mathrm{n}+\theta(1-\xi)(1-\alpha)]}{\left(\frac{\mathrm{K}_{\mathrm{t}}}{\mathrm{n}}\right)^{1-\alpha} .}
\end{aligned}
$$

Given (17), (21a ) and (21b), the “world" stock of capital evolves according to

$$
\mathrm{K}_{\mathrm{t}+1}^{*}=\frac{(1-\xi) \theta(1-\alpha) \mathrm{n}}{[\mathrm{n}+\theta(1-\xi)(1-\alpha)]}\left(\frac{\mathrm{K}_{\mathrm{t}}}{\mathrm{n}}\right)^{1-\alpha}
$$

thus implying that at steady state the "world" stock of capital is

$$
\mathrm{K}^{*}=\mathrm{n}\left[\frac{(1-\xi) \theta(1-\alpha)}{\mathrm{n}+\theta(1-\xi)(1-\alpha)}\right]^{1 / \alpha} \cdot{ }_{10}
$$

Notice that the debt-to-GDP ratio increases with the number of countries $n$ (see equation (21b)), while the steady-state stock of capital of each country decreases with $\mathrm{n}$ (see equation (23)): as in other

\footnotetext{
${ }_{10}$ As the motion of $\mathrm{K}_{\mathrm{t}}$ is governed by the difference equation obtained by linearizing (22) around (23), one can easily check that $\mathrm{K}_{\mathrm{t}}$ converges to $\mathrm{K}^{*}$.
} 
models of inter-country fiscal spillovers (e.g. see Beetsma and Bovenberg, 1999), the individual incentive to cut the deficit diminishes with the number of countries, since the effect of an unilateral reduction in debt on the common capital stock is only " 1 over n".

International coordination ("collusion” among governments)

As the fiscal policies are determined cooperatively by the national governments, the domestic policies' externalities affecting the welfare of foreign individuals are internalized. In the presence of an institutional arrangement making credible the governments' commitments to follow the policies that are determined cooperatively, it is as if the fiscal policies were decided in every $\mathrm{t}$ by maximizing the summation of the national authorities' objectives:

$$
\underset{\omega_{1 \mathrm{t}}, \omega_{2 \mathrm{t}}, \ldots, \omega_{\mathrm{nt}}}{\operatorname{Max}} \sum_{\mathrm{i}=1}^{\mathrm{n}} \mathrm{U}_{\mathrm{it}}
$$

subject to (6), taking into account the optimizing behavior of private agents and anticipating correctly the future fiscal policies, $\mathrm{K}_{\mathrm{t}}, \mathrm{B}_{1 \mathrm{t}}, \mathrm{B}_{2 \mathrm{t}}, \ldots, \mathrm{B}_{\mathrm{nt}}$ and $\mathrm{S}_{1 \mathrm{t}-1}, \mathrm{~S}_{2 \mathrm{t}-1}, \ldots, \mathrm{S}_{\mathrm{nt}-1}$ given. An equilibrium path is characterized by a $n$-tuple of sequences $\left\langle\left\{\omega_{1 \mathrm{z}}^{* *}\right\}_{\mathrm{z}=\mathrm{t}}^{\infty},\left\{\omega_{2 \mathrm{z}}^{* *}\right\}_{\mathrm{z}=\mathrm{t}}^{\infty}, \ldots,\left\{\omega_{\mathrm{nz}}^{* *}\right\}_{\mathrm{z}=\mathrm{t}}^{\infty}\right\rangle$ such that $\left\langle\omega_{1 \mathrm{t}}^{* *}, \omega_{2 \mathrm{t}}^{* *}, \ldots, \omega_{\mathrm{nt}}^{* *}\right\rangle$ solves (24) given the optimal policies determined cooperatively in the future. Differently than in the previous scenario, national tax rates and government borrowing are determined by considering also the effects that national fiscal policies cause on the lifetime utilities of the foreign residents because of their impact on the "world" capital accumulation. Therefore, while conditions (20c)-(20e) are still holding, conditions (20a) and (20b) become, respectively (see the Appendix),

$$
\frac{-(1-\xi)}{1-\tau_{\mathrm{it}}^{\mathrm{y}}}+\frac{\theta(1-\xi)(1-\alpha)(1+\gamma) \mathrm{n}}{\mathrm{K}_{\mathrm{t}+1}} \frac{\partial \mathrm{K}_{\mathrm{t}+1}}{\partial \tau_{\mathrm{it}}^{\mathrm{y}}}+\lambda_{\mathrm{i}} \alpha\left(\frac{\mathrm{K}_{\mathrm{t}}}{\mathrm{n}}\right)^{1-\alpha}=0, \quad \mathrm{i}=1,2, \ldots, \mathrm{n},
$$

and

$$
\frac{\theta(1-\xi)(1-\alpha)(1+\gamma) \mathrm{n}}{\mathrm{K}_{\mathrm{t}+1}} \frac{\partial \mathrm{K}_{\mathrm{t}+1}}{\partial \mathrm{B}_{\mathrm{it}+1}}+\lambda_{\mathrm{i}}=0, \quad \mathrm{i}=1,2, \ldots, \mathrm{n}
$$

By solving the system consisting of (20c)-(20e), (25a) and (25b) (and by eliminating $\lambda_{\mathrm{i}}$ ), one can obtain the policy rules that each national authority must follow along a cooperative equilibrium path: 


$$
\begin{gathered}
\tau_{\mathrm{it}}^{\mathrm{y}^{* *}}=\tau^{\mathrm{y}^{* *}}=1-\frac{(1-\xi)(1+\theta)}{(1+\gamma) \alpha[1+\theta(1-\xi)(1-\alpha)]}, \\
\mathrm{B}_{\mathrm{it}+1}^{* *}=\frac{\mathrm{B}_{\mathrm{t}+1}^{* *}}{\mathrm{n}}=\frac{\theta(1-\xi)[1-(1-\alpha)(1+\gamma)]}{(1+\gamma)[1+\theta(1-\xi)(1-\alpha)]}\left(\frac{\mathrm{K}_{\mathrm{t}}}{\mathrm{n}}\right)^{1-\alpha}, \\
\tau_{\mathrm{it}}^{\mathrm{O}^{* * *}}=1-\frac{\xi \mathrm{K}_{\mathrm{t}}}{(1+\gamma)(1-\alpha) \mathrm{n}\left(\frac{\mathrm{K}_{\mathrm{t}}+\mathrm{B}_{\mathrm{t}}}{\mathrm{n}}\right)[1+\theta(1-\xi)(1-\alpha)]}, \\
\mathrm{G}_{\mathrm{it}}^{* *}=\frac{\gamma}{(1+\gamma)[1+\theta(1-\xi)(1-\alpha)]}\left(\frac{\mathrm{K}_{\mathrm{t}}}{\mathrm{n}}\right)^{1-\alpha} .
\end{gathered}
$$

Given (17), (26a ) and (26b), the "world" stock of capital evolves according to

$$
\mathrm{K}_{\mathrm{t}+1}^{* *}=\frac{(1-\xi) \theta(1-\alpha) \mathrm{n}}{[1+\theta(1-\xi)(1-\alpha)]}\left(\frac{\mathrm{K}_{\mathrm{t}}}{\mathrm{n}}\right)^{1-\alpha}
$$

thus implying that at steady state the "world" stock of capital is

$$
\mathrm{K} * *=\mathrm{n}\left[\frac{(1-\xi) \theta(1-\alpha)}{1+\theta(1-\xi)(1-\alpha)}\right]^{1 / \alpha} \cdot 11
$$

\section{Comparing the two equilibrium paths}

A possible shift from the non-cooperative to the cooperative equilibrium has both short-term and long-term implications. We summarize the effects of this shift into two propositions.

Proposition 1: If in period t the economy moves from the non-cooperative to the cooperative equilibrium, each national government reduces its fiscal deficit by raising the tax rates and diminishing the expenditures as a fraction of the GDP, thus lowering the public debt-GDP ratio. This boosts capital accumulation and has a positive effect on the welfare functions maximized by the national governments. However, this shift does not determine a Pareto improvement, since the generation that is old in $\mathrm{t}$ is worse off.

\footnotetext{
${ }^{11}$ Again, as the motion of $K_{t}$ is governed by the difference equation obtained by linearizing (27) around (28), one can easily check that $\mathrm{K}_{\mathrm{t}}$ converges to $\mathrm{K}^{* *}$.
} 
Proof: One can check that $\tau^{\mathrm{y}^{* * *}}>\tau^{\mathrm{y}^{*}}$, and-given $\mathrm{K}_{\mathrm{t}}$ and $\mathrm{B}_{\mathrm{it}}$-one can check that $\tau_{\mathrm{it}}^{\mathrm{o}^{* *}}>\tau_{\mathrm{it}}^{\mathrm{o}^{*}}, \mathrm{G}_{\mathrm{it}}^{* *}<\mathrm{G}_{\mathrm{it}}^{*}$, $\mathrm{B}_{\mathrm{it}+1}^{* *}<\mathrm{B}_{\mathrm{it}+1}^{*}, \mathrm{~K}_{\mathrm{t}+1}^{* *}>\mathrm{K}_{\mathrm{t}+1}^{*}, \mathrm{U}_{\mathrm{it}}^{* *}>\mathrm{U}_{\mathrm{it}}^{*}, \mathrm{u}_{\mathrm{it}}^{\mathrm{y}^{* * *}}>\mathrm{u}_{\mathrm{it}}^{\mathrm{y}^{*}}$ and $\mathrm{u}_{\mathrm{it}}^{\mathrm{O}^{* *}}<\mathrm{u}_{\mathrm{it}}^{\mathrm{O}^{*}}$.

Proposition 2: The boosting effect on capital accumulation of the shift from the non-cooperative to the cooperative equilibrium determines in the long run an increase in the consumption of all generations and in the governments' provision of the public good, thus raising the individuals' lifetime utility.

Proof: One can check that at steady state $\mathrm{K}^{* *}>\mathrm{K}^{*}, \mathrm{C}^{\mathrm{y}^{* *}}>\mathrm{C}^{\mathrm{y}^{*}}, \mathrm{C}^{\mathrm{O}^{* *}}>\mathrm{C}^{\mathrm{O}^{*}}, \mathrm{G}^{* *}>\mathrm{G}^{*}, \mathrm{u}^{\mathrm{y}^{* *}}>\mathrm{u}^{\mathrm{y}^{*}}$, $\mathrm{u}^{\mathrm{o}^{* *}}>\mathrm{u}^{\mathrm{O}^{*}}$ and $\mathrm{U}^{* *}>\mathrm{U}^{*}$.

\section{Enforcement of the cooperative equilibrium}

It is apparent that each national fiscal policy maker has an incentive to act as a free rider, namely to behave non-cooperatively while the other policy makers continue to behave cooperatively. In this case, indeed, the deviating government could enjoy the benefits of the tighter fiscal policies of the other countries in terms of increased capital accumulation and lower interest rate in the "world" economy, without paying any cost in terms of unpopular tax increases and expenditure cuts. Obviously, symmetry among governments makes the temptation to act as a free rider common to all governments. Therefore, cooperative behavior on the part of the national governments can be an equilibrium only if there is a credible enforcement mechanism. Moreover, in this context, it cannot work the informal enforcement mechanism typical of an infinitely repeated game, where a player abstains from behaving non-cooperatively because of the threat of other players' retaliation in future periods. Indeed, this mechanism is unfeasible because of the short time horizon of each government. This creates the necessity of a formal arrangement (a "Pact") according to which all governments commit themselves to comply with some fiscal constraints and to punish those of them that do not respect the "Pact". This commitment can be credible since the respect of the "Pact" by everybody is in the common interest of all governments (as a matter of fact, $U_{i t}^{* *}>U_{i t}^{*} \forall i$ ).

In the light of this conclusion, we do not elaborate on the specific design of a mechanism for the enforcement of the fiscal cooperation among governments, since our scope is to show that budget rules aimed at avoiding the negative externalities that issuing too much debt generates on foreign governments 
can be credibly enforced even if the authority of last resort in matter of certification and punishment of defiant behavior is an expression of the incumbent governments. One could also argue that the reform of the SGP went in the direction to make it a mere instrument of intergovernmental cooperation of this kind, thus depriving it of its more ambitious objectives in terms of prevention of fiscal short-termism. In this sense, one may maintain that these less ambitious objectives are more consistent with an enforcement mechanism assigning ultimate powers to the incumbent governments.

\section{THE EQUILIBRIUM EMERGING AS THE FISCAL AUTHORITIES CARE ABOUT LONG- TERM WELFARE}

National fiscal policies have spillover effects on the welfare of foreign residents also when they are determined by authorities caring about the utilities of both the living and the future generations. However, to save space, we omit here to treat the case when each national authority acts in full autonomy in order to maximize (8), since it is straightforward that as in the previous section each national authority can do better by cooperating with the other national authorities. Hence, let us assume that the fiscal policies are decided in every $t$ by taking care of the interests of the future generations and by maximizing the summation of the national authorities' objectives:

$$
\left\{\omega_{1 \mathrm{z}}\right\}_{\mathrm{z}=\mathrm{t}}^{\infty},\left\{\omega_{2 \mathrm{z}}\right\}_{\mathrm{z}=\mathrm{t}}^{\infty}, \ldots,\left\{\omega_{\mathrm{nz}}\right\}_{\mathrm{z}=\mathrm{t}}^{\infty} \sum_{\mathrm{z}=\mathrm{t}}^{\infty} \theta^{\mathrm{z}-\mathrm{t}} \sum_{\mathrm{i}=1}^{\mathrm{n}} \mathrm{U}_{\mathrm{iz}}
$$

subject to (6), taking into account the optimizing behavior of private agents, $K_{t}, B_{1 t}, B_{2 t}, \ldots, B_{n t}$ and $S_{1 t-1}$, $\mathrm{S}_{2 \mathrm{t}-1}, \ldots, \mathrm{S}_{\mathrm{nt}-1}$ given.

Differently than in the solution to (24), national tax rates and government borrowing are determined by considering also the effects that national fiscal policies cause on the lifetime utilities of the not-yet born individuals because of their impact on the "world" capital accumulation. Therefore, while conditions (20c)(20e) are still holding, conditions (20a) and (20b) become, respectively (see the Appendix),

$$
\frac{-(1-\xi)}{1-\tau_{\mathrm{it}}^{\mathrm{y}}}+\frac{\theta(2-\xi)(1-\alpha)(1+\gamma) \mathrm{n}}{[1-\theta(1-\alpha)] \mathrm{K}_{\mathrm{t}+1}} \frac{\partial \mathrm{K}_{\mathrm{t}+1}}{\partial \tau_{\mathrm{it}}^{\mathrm{y}}}+\lambda_{\mathrm{i}} \alpha\left(\frac{\mathrm{K}_{\mathrm{t}}}{\mathrm{n}}\right)^{1-\alpha}=0, \quad \mathrm{i}=1,2, \ldots, \mathrm{n},
$$

and 


$$
\frac{\theta(2-\xi)(1-\alpha)(1+\gamma) \mathrm{n}}{[1-\theta(1-\alpha)] \mathrm{K}_{\mathrm{t}+1}} \frac{\partial \mathrm{K}_{\mathrm{t}+1}}{\partial \mathrm{B}_{\mathrm{it}+1}}+\lambda_{\mathrm{i}}=0, \quad \mathrm{i}=1,2, \ldots, \mathrm{n} .
$$

By solving the system consisting of (20c)-(20e), (30a) and (30b) (and by eliminating $\lambda_{\mathrm{i}}$ ), one can obtain the policy rules that each national authority must adopt along a cooperative-equilibrium path where also the interests of the future generations are taken into account:

$$
\begin{gathered}
\tau_{\mathrm{it}}^{\mathrm{y}^{* * *}}=\tau^{\mathrm{y}^{* * * *}}=1-\frac{(1-\xi)(1+\theta)[1-\theta(1-\alpha)]}{(1+\gamma) \alpha[1+\theta(1-\xi)(1-\alpha)]}, \\
\mathrm{B}_{\mathrm{it}+1}^{* * *}=\frac{\mathrm{B}_{\mathrm{t}+1}^{* * * *}}{\mathrm{n}}=\frac{\theta\{(1-\xi)[1-(1-\alpha)(1+\gamma)]-(1-\alpha)[1+\gamma+\theta(1-\xi)]\}}{(1+\gamma)[1+\theta(1-\xi)(1-\alpha)]}\left(\frac{\mathrm{K}_{\mathrm{t}}}{\mathrm{n}}\right)^{1-\alpha}, \\
\tau_{\mathrm{it}}^{\mathrm{O}^{* * * *}}=1-\frac{\xi[1-\theta(1-\alpha)] \mathrm{K}_{\mathrm{t}}}{(1+\gamma)(1-\alpha) \mathrm{n}\left(\frac{\mathrm{K}_{\mathrm{t}}+\mathrm{B}_{\mathrm{t}}}{\mathrm{n}}\right)[1+\theta(1-\xi)(1-\alpha)]}, \\
\mathrm{G}_{\mathrm{it}}^{* * *}=\frac{\gamma[1-\theta(1-\alpha)]}{(1+\gamma)[1+\theta(1-\xi)(1-\alpha)]}\left(\frac{\mathrm{K}_{\mathrm{t}}}{\mathrm{n}}\right)^{1-\alpha},
\end{gathered}
$$

Given (17), (31a ) and (31b), the stock of capital evolves according to

$$
\mathrm{K}_{\mathrm{t}+1}^{* * *}=\frac{(2-\xi) \theta(1-\alpha) \mathrm{n}}{[1+\theta(1-\xi)(1-\alpha)]}\left(\frac{\mathrm{K}_{\mathrm{t}}}{\mathrm{n}}\right)^{1-\alpha}
$$

thus implying that the steady-state stock of capital is

$$
\mathrm{K} * * *=\mathrm{n}\left[\frac{(2-\xi) \theta(1-\alpha)}{1+\theta(1-\xi)(1-\alpha)}\right]^{1 / \alpha} \cdot{ }^{12}
$$

\section{Comparing the two paths emerging when the national authorities cooperate}

Also a possible shift from the cooperative equilibrium emerging when the fiscal authorities care only about the utilities of the living generations to the cooperative equilibrium emerging when the fiscal authorities care also about the welfare of the future generations has both short-term and long-term implications. We summarize the effects of this shift into two propositions.

Proposition 3: If in period t the economy moves from the cooperative equilibrium emerging when only the interests of the living generations are taken into account to the cooperative equilibrium emerging when also

\footnotetext{
${ }^{12}$ Again, as the motion of $K_{t}$ is governed by the difference equation obtained by linearizing (32) around (33), one can easily check that $\mathrm{K}_{\mathrm{t}}$ converges to $\mathrm{K}^{* * *}$.
} 
the interests of the future generations are considered, each national authority reduces its fiscal deficit by raising the tax rates and diminishing the expenditures as a fraction of the GDP, thus lowering the public debt-GDP ratio. This boosts capital accumulation but has a negative effect on current social welfare.

Proof: One can check that $\tau^{\mathrm{y}^{* * *}}>\tau^{\mathrm{y}^{* *}}$, and-given $\mathrm{K}_{\mathrm{t}}$ and $\mathrm{B}_{\mathrm{it}}$-one can check that $\tau_{\mathrm{it}}^{\mathrm{o}^{* * * *}}>\tau_{\mathrm{it}}^{\mathrm{O}^{* * *}}$, $\mathrm{G}_{\mathrm{it}}^{* * *}<\mathrm{G}_{\mathrm{it}}^{* *}, \mathrm{~B}_{\mathrm{it}+1}^{* * *}<\mathrm{B}_{\mathrm{it}+1}^{* *}, \mathrm{~K}_{\mathrm{t}+1}^{* * *}>\mathrm{K}_{\mathrm{t}+1}^{* *}, \mathrm{U}_{\mathrm{it}}^{* * *}<\mathrm{U}_{\mathrm{it}}^{* *}$ and $\mathrm{u}_{\mathrm{it}}^{\mathrm{O} * * *}<\mathrm{u}_{\mathrm{it}}^{\text {O** }}$.

Proposition 4: The boosting effect on capital accumulation of a shift from the cooperative equilibrium emerging under short-termism to the cooperative equilibrium emerging when the authorities care also about the interests of the future generations determines in the long run an increase in the consumption of all generations and in the governments' provision of the public good, thus raising the individuals' lifetime utility.

Proof: One can check that at steady state $\mathrm{K}^{* * *}>\mathrm{K}^{* *}, \mathrm{C}^{\mathrm{y}^{* * *}}>\mathrm{C}^{\mathrm{y}^{* *}}, \mathrm{C}^{\mathrm{O}^{* * *}}>\mathrm{C}^{\mathrm{O}^{* *}}, \mathrm{G}^{* * *}>\mathrm{G}^{* *}$, $\mathrm{u}^{\mathrm{y}^{* * * *}}>\mathrm{u}^{\mathrm{y}^{* * *}}, \mathrm{u}^{\mathrm{o}^{* * *}}>\mathrm{u}^{\mathrm{o} * *}$ and $\mathrm{U}^{* * * *}>\mathrm{U}^{* *}$.

Enforcement of the cooperative equilibrium emerging when the fiscal authorities care also about the future generations

It is apparent that national governments maximizing the welfare of the living generations, i.e. maximizing $\mathrm{U}_{\mathrm{it}}$, would never enforce a "Pact" dictating fiscal policies that lower their objective functions below the level that they could reach by respecting softer fiscal constraints (as a matter of fact, $\mathrm{U}_{\mathrm{it}}^{* * *}<\mathrm{U}_{\mathrm{it}}^{* *} \forall \mathrm{i}$ ). Facing such a "Pact", national governments would collude for not fully respecting it. This is true in spite of the fact that this tighter "Pact" would lead in the long run to a welfare improvement $\left(\mathrm{U}^{* * *}>\mathrm{U}^{* *}\right)$. In other words, a "Pact" imposing fiscal policies that are optimal from a long-term perspective cannot be credibly enforced by national governments having shorter-term points of view. This more ambitious "Pact" could be credibly enforced by an authority independent of the national governments, having as its mission the implementation of guidelines binding for all fiscal authorities and endowed with the powers for imposing the respect of these guidelines. 
These conclusions may help explaining why incumbent governments in possession of ultimate powers in matter of enforcement colluded successfully for not respecting the tighter interpretation of the SGP.

\section{CONCLUSION}

As Buiter states in his "Ninth Commandment" for a fiscal rule in the $\mathrm{E}(\mathrm{M}) \mathrm{U}$ : "For rules to be credible, one of two conditions must be met: Either the rules are self-enforcing, or they are enforced consistently, through a combination of sticks and carrots, by an external agent" (Buiter, 2003, p.96). This paper intended to show that the credibility problem of the SGP followed from the fact that in its formulation and functioning neither of these conditions were met. Consistently with this diagnosis, Wyplosz (2002) proposed of delegating to a Fiscal Policy Committee independent of national governments the responsibility and the power of setting and enforce the fiscal guidelines to be followed by all member countries, leaving the more political allocative and distributive targets to national governments. It was very unlikely that many European governments were willing to surrender their sovereignty in these matters to such a body. As a matter of fact, recent events have shown that more ambitious objectives are unrealistic and that for any practical purposes the SGP has to be intended solely as an arrangement for permitting some coordination and cooperation among national governments with full control over their fiscal policy. Also this conclusion, indeed, is consistent with the spirit of this paper.

The analysis of the paper was conducted within a very stylized framework so as to achieve neat results and not to dim their derivations with unnecessary complications. However, an extension to which it would be worth to devote further work amounts of differentiating the countries with respect to their initial conditions and size. 


\section{References}

Alesina, A. and Tabellini, G. (1990). “A Positive Theory of Fiscal Deficits and Government Debt.” Review of Economic Studies, 57, 403-414.

Allsopp, C.J. and Artis, M.J. (2003). “The Assessment: EMU, Four Years on.” Oxford Review of Economic Policy, 19(1), 1-29.

Allsopp, C.J. and Vines, D. (1998). “The Assessment: Macroeconomic Policy after EMU.” Oxford Review of Economic Policy, 14(3), 1-23.

Ardegna S., Caselli F. and Lane T. (2004) "Fiscal Discipline and the Cost of Public Debt Service: Some Estimates for the OECD countries", NBER Working Paper No. 10788.

Baele, L., Ferrando, A., Hördahl, P., Krylova, E. and Monnet, C. (2004). "Measuring Financial Integration in the Euro Area.” ECB Occasional Papers Series No. 14, April.

Beetsma, R. and Bovenberg, L. (1999). "Does Monetary Unification Lead to Excessive Debt Accumulation?" Journal of Public Economics, 74, 199-235.

Beetsma, R. and Uhlig, H. (1999). ”An Analysis of the Stability and Growth Pact.” Economic Journal, 109, 546-571.

Beltrametti, L. and Bonatti, L. (2004). "Does International Coordination of Pension Policies Boost Capital Accumulation?" Journal of Public Economics, 88, 113-129.

Blanchard, O.J. (1985). “Debt, Deficits and Finite Horizons.” Journal of Political Economy, 93, 223-247..

Breedon, F., Henry, B.,Williams, G. "Long Term Real Interest Rate: Evidence on the Global Capital Market", Oxford Review of Economic Policy, 15(2), 128-142

Buiter, W. H. (2003). "Ten Commandments for a Fiscal Rule in the E(M)U." Oxford Review of Economic Policy, 19(1), 84-99.

Buti, M., Eijffinger, S. and Franco, D. (2003). "Revising EMU's Stability Pact: a Pragmatic Way Forward.” Oxford Review of Economic Policy, 19(1), 100-111.

Buti, M. and Van den Noord, P. (2003). "Discretionary Fiscal Policy and Elections: The Experience of the Early Years of EMU.” OCSE, Working Papers No. 351.

Chari, V.V. and Kehoe, P.J. (1990). "International Coordination of Fiscal Policy in Limiting Economies." Journal of Political Economy, 98, 617-636. 
Chari, V.V. and Kehoe, P.J. (2003). "On the Desirability of Fiscal Constraints in a Monetary Union.” Federal Reserve Bank of Minneapolis, Research Department Staff Report 330.

Chinn, M. and Frankel J. (2005) "The Euro Area and World Interest Rates”, mimeo

Cukierman, A. and Metzler, A. (1989). "A Political Theory of Government Debt and Deficits in a NeoRicardian Framework.” American Economic Review, 79, 713-748.

Dixit, A. and Lambertini, L. (2001). "Monetary-Fiscal Policy Interactions and Commitment versus Discretion in a Monetary Union," European Economic Review, 45, 977-987.

ECB (2003). Monthly Bulletin, October.

ECB (2004). Monthly Bulletin, April.

ECB (2005). Monthly Bulletin, August.

Eichengreen, B. and Wyplosz, C. (1998). ”The Stability Pact: More than a Minor Nuisance?" Economic Policy, 13, 67-113.

Faini, R. (2006) “Fiscal Policy and Interest Rates in Europe.” Economic Policy, 21, 443-489.

Fatás, A. and Mihov, I. (2003). "On Constraining Fiscal Policy Discretion in EMU” Oxford Review of Economic Policy, 19(1), 112-131.

Gale, W. and Orszag, P.R. (2003). “The Economic Effects of Long-Term Fiscal Discipline.” UrbanBrookings Tax Policy Center Discussion Paper No. 8, April.

Gersbach, H. (1998). "Incentive Contracts and Elections for Politicians and the Down-up Problem." Universität Heidelberg, Working Paper.

Hallerberg, M., Strauch R. and von Hagen, J. (2004). "The Design of Fiscal Rules and Forms of Governance in European Union Countries.” ECB Working Paper Series No. 419, December.

Kehoe, P. J. (1987). “Coordination of Fiscal Policies in a World Economy.” Journal of Monetary Economics, 19, 349-376.

Laubach, T. (2003). “New Evidence on the Interest Rate Effects of Budget Deficits and Debt.” Board of Governors of the Federal Reserve System, May

Nordhaus, W.D. (1975). “The Political Business Cycle.” Review of Economic Studies, 42, 169-182.

Perotti, R. (2002). "Estimating the Effects of Fiscal Policy in OECD Countries." ECB Working Paper No. 168. 
Persson, T. and Svensson, L. (1989). "Why a Stubborn Conservative Would Run a Deficit: Policy with Time Inconsistent Preferences.” Quarterly Journal of Economics, 104, 325-345.

Persson, T. and Tabellini, G. (1990). Macroeconomic Policy, Credibility and Politics. Chur, Harwood Academic Publishing.

Pisani-Ferry, J. (2002). "Fiscal Discipline and Policy Coordination in the Eurozone: Assessment and Proposals." Note for the Group of the Economic Analysis of the European Commission, April.

Rubin R.E., Orszag, P.R. and Sinai A. (2004). "Sustained Budget Deficits: Longer-Run U.S. Economic Performance and the Risk of Financial and Fiscal Disarray." Paper presented at the AEA-NAEFA Joint Session, ASSA Annual Meeting, January 4, San Diego, CA.

Uhlig, H. (2002). “One Money, but Many Fiscal Policies in Europe: what are the Consequences?” Humboldt University Discussion Paper No. 32, Berlin.

Welsch, H. (2000). “Domestic Fiscal policy in a Monetary Union: What Are the Spillovers?” Jahrbücher für Nationalökonomie, 220/3, 327-342.

Wyplosz, C. (2002). “Fiscal Discipline in EMU: Rules or Institutions?” Paper prepared for the April 16, 2002 meeting of the Group of Economic Analysis of the European Commission, April.

\section{APPENDIX}

1 The dynamic game among national governments

Knowing consumption, savings, wages, "world" interest rate and capital stock as functions of the authorities' fiscal policies, one can derive the subgame-perfect equilibrium of the game played when each national authority acts independently by supposing that there is a final period $\mathrm{T}$ and by solving it backwards period by period. The problem to be solved in $\mathrm{T}$ by the authority $\mathrm{i}$ is the following:

$$
\underset{\tau_{\mathrm{iT}}^{\mathrm{y}}, \tau_{\mathrm{i} T}^{\mathrm{o}}, \mathrm{G}_{\mathrm{iT}}}{\max } \xi \ln \left[\mathrm{S}_{\mathrm{iT}-1}\left(1-\tau_{\mathrm{iT}}^{\mathrm{o}}\right)(1-\alpha)\left(\frac{\mathrm{K}_{\mathrm{T}}}{\mathrm{n}}\right)^{-\alpha}\right]+(1-\xi) \ln \left\{\left(1-\tau_{\mathrm{iT}}^{\mathrm{y}}\right) \alpha\left(\frac{\mathrm{K}_{\mathrm{T}}}{\mathrm{n}}\right)^{1-\alpha}\right\}+\gamma \mathrm{n}\left(\mathrm{G}_{\mathrm{iT}}\right)
$$

subject to $\mathrm{G}_{\mathrm{iT}}+(1-\alpha)\left(\frac{\mathrm{K}_{\mathrm{T}}}{\mathrm{n}}\right)^{-\alpha} \mathrm{B}_{\mathrm{iT}} \leq \tau_{\mathrm{iT}}^{\mathrm{o}} \mathrm{S}_{\mathrm{iT}-1}(1-\alpha)\left(\frac{\mathrm{K}_{\mathrm{T}}}{\mathrm{n}}\right)^{-\alpha}+\tau_{\mathrm{iT}}^{\mathrm{y}} \alpha\left(\frac{\mathrm{K}_{\mathrm{T}}}{\mathrm{n}}\right)^{1-\alpha}, \mathrm{K}_{\mathrm{T}}, \mathrm{B}_{\mathrm{iT}}$, and $\mathrm{S}_{\mathrm{iT}-1}$ given. 
Note that $\mathrm{K}_{\mathrm{T}+1}=0, \mathrm{~B}_{\mathrm{iT}+1}=0$ and $\mathrm{S}_{\mathrm{iT}}=0 \forall \mathrm{i}$ : as long as the impact of the current fiscal policy on next-period capital stock does not enter the authorities' decision problem (since period $\mathrm{T}$ is assumed to be the last of the economy's history), it makes no difference whether the fiscal policies are decided in full autonomy or with international coordination (there is no interdependence among national policies). ${ }^{13}$ Assuming symmetry across countries $\left(\mathrm{B}_{1 \mathrm{~T}}=\mathrm{B}_{2 \mathrm{~T}}=\ldots=\mathrm{B}_{\mathrm{nT}}\right.$ and $\left.\mathrm{S}_{1 \mathrm{~T}-1}=\mathrm{S}_{2 \mathrm{~T}-1}=\ldots=\mathrm{S}_{\mathrm{nT}-1}\right)$, the conditions to be satisfied for an interior solution in $\mathrm{T}$ are:

$$
\begin{aligned}
& \frac{-(1-\xi)}{1-\tau_{\mathrm{i} T}^{\mathrm{y}}}+\lambda_{\mathrm{i}} \alpha\left(\frac{\mathrm{K}_{\mathrm{T}}}{\mathrm{n}}\right)^{1-\alpha}=0, \quad \mathrm{i}=1,2, \ldots, \mathrm{n}, \\
& \frac{-\xi}{1-\tau_{\mathrm{iT}}^{\mathrm{o}}}+\lambda_{\mathrm{i}}\left(\frac{\mathrm{K}_{\mathrm{T}}+\mathrm{B}_{\mathrm{T}}}{\mathrm{n}}\right)(1-\alpha)\left(\frac{\mathrm{K}_{\mathrm{T}}}{\mathrm{n}}\right)^{-\alpha}=0, \mathrm{i}=1,2, \ldots, \mathrm{n}, \\
& \frac{\gamma}{\mathrm{G}_{\mathrm{iT}}}-\lambda_{\mathrm{i}}=0, \quad \mathrm{i}=1,2, \ldots, \mathrm{n}, \\
& \tau_{\mathrm{iT}}^{\mathrm{o}}\left(\frac{\mathrm{K}_{\mathrm{T}}+\mathrm{B}_{\mathrm{T}}}{\mathrm{n}}\right)(1-\alpha)\left(\frac{\mathrm{K}_{\mathrm{T}}}{\mathrm{n}}\right)^{-\alpha}+\tau_{\mathrm{iT}}^{\mathrm{y}} \alpha\left(\frac{\mathrm{K}_{\mathrm{T}}}{\mathrm{n}}\right)^{1-\alpha}-(1-\alpha)\left(\frac{\mathrm{K}_{\mathrm{T}}}{\mathrm{n}}\right)^{-\alpha} \frac{\mathrm{B}_{\mathrm{T}}}{\mathrm{n}}-\mathrm{G}_{\mathrm{iT}}=0, \mathrm{i}=1,2, \ldots, \mathrm{n},
\end{aligned}
$$

where $\lambda_{i}$ is a Lagrange multiplier. By solving (A2) and eliminating $\lambda_{i}$, one can obtain the equilibrium policy rules of a national government in period $\mathrm{T}$ :

$$
\begin{gathered}
\tau_{\mathrm{T}}^{\mathrm{y}^{*}=1-\frac{(1-\xi)}{(1+\gamma) \alpha}}, \\
\tau_{\mathrm{T}}^{\mathrm{O}^{*}}=1-\frac{\xi \mathrm{K}_{\mathrm{T}}}{\mathrm{n}(1+\gamma)(1-\alpha)\left(\frac{\mathrm{K}_{\mathrm{T}}+\mathrm{B}_{\mathrm{T}}}{\mathrm{n}}\right)}, \\
\mathrm{G}_{\mathrm{T}}^{*}=\frac{\gamma}{(1+\gamma)}\left(\frac{\mathrm{K}_{\mathrm{T}}}{\mathrm{n}}\right)^{1-\alpha}
\end{gathered}
$$

The problem to be solved in T-1 by each national authority caring only about the well-being of the living generations is the following:

\footnotetext{
${ }^{13}$ For the same reason, in $\mathrm{T}$ it makes no difference whether the authorities cares only of the utilities about the living generations or also about the utilities of the future generations.
} 


$$
\begin{gathered}
\underset{\omega_{\mathrm{iT}-1}}{\operatorname{Man}}\left[\mathrm{S}_{\mathrm{iT}-2}\left(1-\tau_{\mathrm{iT}-1}^{\mathrm{o}}\right)(1-\alpha)\left(\frac{\mathrm{K}_{\mathrm{T}-1}}{\mathrm{n}}\right)^{-\alpha}\right]+(1-\xi) \ln \left[\frac{\left(1-\tau_{\mathrm{iT}-1}^{\mathrm{y}}\right)}{(1+\theta)} \alpha\left(\frac{\mathrm{K}_{\mathrm{T}-1}}{\mathrm{n}}\right)^{1-\alpha}\right]+\gamma \ln \left(\mathrm{G}_{\mathrm{iT}-1}\right)+ \\
+(1-\xi) \theta\left\{\ln \left(\frac{\xi}{1+\gamma}\right)+\gamma \mathrm{n}\left(\frac{\gamma}{1+\gamma}\right)+(1+\gamma)(1-\alpha)\left[\ln \left(\mathrm{K}_{\mathrm{T}}\right)-\ln (\mathrm{n})\right]\right\}
\end{gathered}
$$

subject to $\mathrm{G}_{\mathrm{iT}-1}+(1-\alpha)\left(\frac{\mathrm{K}_{\mathrm{T}-1}}{\mathrm{n}}\right)^{-\alpha} \mathrm{B}_{\mathrm{iT}-1} \leq \tau_{\mathrm{iT}-1}^{\mathrm{o}} \mathrm{S}_{\mathrm{iT}-2}(1-\alpha)\left(\frac{\mathrm{K}_{\mathrm{T}-1}}{\mathrm{n}}\right)^{-\alpha}+\tau_{\mathrm{iT}-1}^{\mathrm{y}} \alpha\left(\frac{\mathrm{K}_{\mathrm{T}-1}}{\mathrm{n}}\right)^{1-\alpha}+\mathrm{B}_{\mathrm{iT}}$, taking as given the policies of all other authorities operating in $\mathrm{T}-1, \mathrm{~K}_{\mathrm{T}-1}, \mathrm{~B}_{\mathrm{iT}-1}$ and $\mathrm{S}_{\mathrm{iT}-2}$ given, and where $\mathrm{K}_{\mathrm{T}}$ is given by (17) (with $\mathrm{t}=\mathrm{T}-1$ ). Note that in period $\mathrm{T}-1$, differently than in $\mathrm{T}$, each national authority must take into account also the impact that its current policies have on the lifetime utility of its living citizens' via its effect on next-period "world" capital stock. This creates an interdependence among national policies. Assuming again symmetry across countries, the conditions to be satisfied for an interior solution in T-1 are given by (20) (with $\mathrm{t}=\mathrm{T}-1$ ), from which one can derive the optimal response functions of the $\mathrm{n}$ countries. A NashCournot equilibrium of the game in which the national authorities are involved in period T-1 is a fixed point in the space of the n-countries' response functions. One can check that this fixed point is unique and solve (20) for the equilibrium policy rules of the national governments in T-1 (by exploiting the fact that under symmetry these policy rules are the same for all countries). Hence, one obtains (21) (with t=T-1).

The problem to be solved in T-2 by each national authority caring only about the well-being of the living generations is the following:

$$
\begin{array}{r}
\operatorname{Max}_{\omega_{\mathrm{T}-2}} \xi \ln \left[\mathrm{S}_{\mathrm{iT}-3}\left(1-\tau_{\mathrm{iT}-2}^{\mathrm{o}}\right)(1-\alpha)\left(\frac{\mathrm{K}_{\mathrm{T}-2}}{\mathrm{n}}\right)^{-\alpha}\right]+(1-\xi) \ln \left[\frac{\left(1-\tau_{\mathrm{iT}-2}^{\mathrm{y}}\right)}{(1+\theta)} \alpha\left(\frac{\mathrm{K}_{\mathrm{T}-2}}{\mathrm{n}}\right)^{1-\alpha}\right]+\gamma \mathrm{nn}\left(\mathrm{G}_{\mathrm{iT}-2}\right)+ \\
+(1-\xi) \theta\left\{\ln \left(\frac{\xi}{1+\gamma}\right)+\gamma \ln \left(\frac{\gamma}{1+\gamma}\right)+(1+\gamma)\{\ln (\mathrm{n})-\ln [\mathrm{n}+\theta(1-\xi)(1-\alpha)]\}+(1+\gamma)(1-\alpha)\left[\ln \left(\mathrm{K}_{\mathrm{T}-1}\right)-\ln (\mathrm{n})\right]\right\} \quad(\mathrm{A} 5)
\end{array}
$$

subject to $\mathrm{G}_{\mathrm{iT}-2}+(1-\alpha)\left(\frac{\mathrm{K}_{\mathrm{T}-2}}{\mathrm{n}}\right)^{-\alpha} \mathrm{B}_{\mathrm{iT}-2} \leq \tau_{\mathrm{iT}-2}^{\mathrm{o}} \mathrm{S}_{\mathrm{iT}-3}(1-\alpha)\left(\frac{\mathrm{K}_{\mathrm{T}-2}}{\mathrm{n}}\right)^{-\alpha}+\tau_{\mathrm{iT}-2}^{\mathrm{y}} \alpha\left(\frac{\mathrm{K}_{\mathrm{T}-2}}{\mathrm{n}}\right)^{1-\alpha}+\mathrm{B}_{\mathrm{iT}-1}$, taking as given the policies of all other authorities operating in $\mathrm{T}-2, \mathrm{~K}_{\mathrm{T}-2}, \mathrm{~B}_{\mathrm{iT}-2}$ and $\mathrm{S}_{\mathrm{iT}-3}$ given, and where $\mathrm{K}_{\mathrm{T}-1}$ is given by (17) (with $\mathrm{t}=\mathrm{T}-2$ ). Assuming again symmetry across countries, the conditions to be satisfied for an interior solution in T-2 are still given by (20) (with $\mathrm{t}=\mathrm{T}-2$ ), thus obtaining the policy rules (21) (with $\mathrm{t}=\mathrm{T}-2$ ). 
Iterating this procedure $\mathrm{j}$-times and letting $\mathrm{T} \rightarrow \infty$ and $\mathrm{j} \rightarrow \infty$, one still obtains the (time-invariant) equilibrium rules (21).

\section{Cooperation among national governments}

To derive the unique equilibrium path of this "world" economy when there is cooperation among national governments, namely when the fiscal policy are determined by maximizing (24), suppose again that $\mathrm{T}$ is the final period of the economy. In $\mathrm{T}$ there is no interdependence among national policies, and the equilibrium policy rules are still given by (A2). In contrast, the first-order conditions to be satisfied for a maximum when the national governments collude in T-1 are not the same as in the absence of coordination. Indeed, the problem to be solved in T-1 when the national governments cooperate is the following:

$$
\begin{gathered}
\underset{\omega_{\mathrm{IT}-1}, \omega_{2 \mathrm{~T}-1}, \ldots, \omega_{\mathrm{nT}-1}}{\operatorname{Max}=1} \sum_{\mathrm{i}}^{\mathrm{n}} \xi \ln \left[\mathrm{S}_{\mathrm{iT}-2}\left(1-\tau_{\mathrm{iT}-1}^{\mathrm{o}}\right)(1-\alpha)\left(\frac{\mathrm{K}_{\mathrm{T}-1}}{\mathrm{n}}\right)^{-\alpha}\right]+(1-\xi) \ln \left[\frac{\left(1-\tau_{\mathrm{iT}-1}^{\mathrm{y}}\right)}{(1+\theta)} \alpha\left(\frac{\mathrm{K}_{\mathrm{T}-1}}{\mathrm{n}}\right)^{1-\alpha}\right]+\gamma \mathrm{nn}\left(\mathrm{G}_{\mathrm{iT}-1}\right)+ \\
+(1-\xi) \theta\left\{\ln \left(\frac{\xi}{1+\gamma}\right)+\gamma \mathrm{n}\left(\frac{\gamma}{1+\gamma}\right)+(1+\gamma)(1-\alpha)\left[\ln \left(\mathrm{K}_{\mathrm{T}}\right)-\ln (\mathrm{n})\right]\right\}
\end{gathered}
$$

subject to

$$
\begin{aligned}
& \mathrm{G}_{1 \mathrm{~T}-1}+(1-\alpha)\left(\frac{\mathrm{K}_{\mathrm{T}-1}}{\mathrm{n}}\right)^{-\alpha} \mathrm{B}_{1 \mathrm{~T}-1} \leq \tau_{1 \mathrm{~T}-1}^{\mathrm{o}} \mathrm{S}_{1 \mathrm{~T}-2}(1-\alpha)\left(\frac{\mathrm{K}_{\mathrm{T}-1}}{\mathrm{n}}\right)^{-\alpha}+\tau_{1 \mathrm{~T}-1}^{\mathrm{y}} \alpha\left(\frac{\mathrm{K}_{\mathrm{T}-1}}{\mathrm{n}}\right)^{1-\alpha}+\mathrm{B}_{1 \mathrm{~T}} \\
& \mathrm{G}_{2 \mathrm{~T}-1}+(1-\alpha)\left(\frac{\mathrm{K}_{\mathrm{T}-1}}{\mathrm{n}}\right)^{-\alpha} \mathrm{B}_{2 \mathrm{~T}-1} \leq \tau_{2 \mathrm{~T}-1}^{\mathrm{o}} \mathrm{S}_{2 \mathrm{~T}-2}(1-\alpha)\left(\frac{\mathrm{K}_{\mathrm{T}-1}}{\mathrm{n}}\right)^{-\alpha}+\tau_{2 \mathrm{~T}-1}^{\mathrm{y}} \alpha\left(\frac{\mathrm{K}_{\mathrm{T}-1}}{\mathrm{n}}\right)^{1-\alpha}+\mathrm{B}_{2 \mathrm{~T}} \\
& \cdot \\
& \cdot \\
& \cdot \\
& \mathrm{G}_{\mathrm{nT}-1}+(1-\alpha)\left(\frac{\mathrm{K}_{\mathrm{T}-1}}{\mathrm{n}}\right)^{-\alpha} \mathrm{B}_{\mathrm{nT}-1} \leq \tau_{\mathrm{nT}-1}^{\mathrm{o}} \mathrm{S}_{\mathrm{nT}-2}(1-\alpha)\left(\frac{\mathrm{K}_{\mathrm{T}-1}}{\mathrm{n}}\right)^{-\alpha}+\tau_{\mathrm{nT}-1}^{\mathrm{y}} \alpha\left(\frac{\mathrm{K}_{\mathrm{T}-1}}{\mathrm{n}}\right)^{1-\alpha}+\mathrm{B}_{\mathrm{nT}},
\end{aligned}
$$

$\mathrm{K}_{\mathrm{T}-1}, \mathrm{~B}_{1 \mathrm{~T}-1}, \mathrm{~B}_{2 \mathrm{~T}-1}, \ldots, \mathrm{B}_{\mathrm{nT}-1}$, and $\mathrm{S}_{1 \mathrm{~T}-2}, \mathrm{~S}_{2 \mathrm{~T}-2}, \ldots, \mathrm{S}_{\mathrm{nT}-2}$ given, and where $\mathrm{K}_{\mathrm{T}}$ is given by (17) (with $\mathrm{t}=\mathrm{T}-1$ ).

Assuming symmetry across countries $\left(\mathrm{B}_{1 \mathrm{~T}-1}=\mathrm{B}_{2 \mathrm{~T}-1}=\ldots=\mathrm{B}_{\mathrm{nT}-1}\right.$ and $\left.\mathrm{S}_{1 \mathrm{~T}-2}=\mathrm{S}_{2 \mathrm{~T}-2}=\ldots=\mathrm{S}_{\mathrm{nT}-2}\right)$, the conditions to be satisfied for an interior solution in $\mathrm{T}-1$ are given by (20c)-(20e) and by (25a)-(25b) (with $\mathrm{t}=\mathrm{T}-1)$, thus obtaining the policy rules (26) (with $\mathrm{t}=\mathrm{T}-1$ ).

The problem to be solved in T-2 when the national governments cooperate is the following: 


$$
\begin{aligned}
\underset{\omega_{1 \mathrm{~T}-2}, \omega_{2 \mathrm{~T}-2}, \ldots, \omega_{\mathrm{nT}-2}}{\operatorname{Max}=1} & \sum_{\mathrm{i}}^{\mathrm{n}} \xi \ln \left[\mathrm{S}_{\mathrm{iT}-3}\left(1-\tau_{\mathrm{iT}-2}^{\mathrm{o}}\right)(1-\alpha)\left(\frac{\mathrm{K}_{\mathrm{T}-2}}{\mathrm{n}}\right)^{-\alpha}\right]+(1-\xi) \ln \left[\frac{\left(1-\tau_{\mathrm{iT}-2}^{\mathrm{y}}\right)}{(1+\theta)} \alpha\left(\frac{\mathrm{K}_{\mathrm{T}-2}}{\mathrm{n}}\right)^{1-\alpha}\right]+\gamma \ln \left(\mathrm{G}_{\mathrm{iT}-2}\right)+ \\
& +(1-\xi) \theta\left\{\ln \left(\frac{\xi}{1+\gamma}\right)+\gamma \mathrm{n}\left(\frac{\gamma}{1+\gamma}\right)-(1+\gamma) \ln [1+\theta(1-\xi)(1-\alpha)]+(1+\gamma)(1-\alpha)\left[\ln \left(\mathrm{K}_{\mathrm{T}-1}\right)-\ln (\mathrm{n})\right]\right\} \quad \text { (A7) }
\end{aligned}
$$

subject to

$$
\begin{gathered}
\mathrm{G}_{1 \mathrm{~T}-2}+(1-\alpha)\left(\frac{\mathrm{K}_{\mathrm{T}-2}}{\mathrm{n}}\right)^{-\alpha} \mathrm{B}_{1 \mathrm{~T}-2} \leq \tau_{1 \mathrm{~T}-2}^{\mathrm{o}} \mathrm{S}_{1 \mathrm{~T}-3}(1-\alpha)\left(\frac{\mathrm{K}_{\mathrm{T}-2}}{\mathrm{n}}\right)^{-\alpha}+\tau_{1 \mathrm{~T}-2}^{\mathrm{y}} \alpha\left(\frac{\mathrm{K}_{\mathrm{T}-2}}{\mathrm{n}}\right)^{1-\alpha}+\mathrm{B}_{1 \mathrm{~T}-1} \\
\mathrm{G}_{2 \mathrm{~T}-2}+(1-\alpha)\left(\frac{\mathrm{K}_{\mathrm{T}-2}}{\mathrm{n}}\right)^{-\alpha} \mathrm{B}_{2 \mathrm{~T}-2} \leq \tau_{2 \mathrm{~T}-2}^{\mathrm{o}} \mathrm{S}_{2 \mathrm{~T}-3}(1-\alpha)\left(\frac{\mathrm{K}_{\mathrm{T}-2}}{\mathrm{n}}\right)^{-\alpha}+\tau_{2 \mathrm{~T}-2}^{\mathrm{y}} \alpha\left(\frac{\mathrm{K}_{\mathrm{T}-2}}{\mathrm{n}}\right)^{1-\alpha}+\mathrm{B}_{2 \mathrm{~T}-1} \\
\cdot \\
\cdot \\
\cdot \\
\cdot \\
\mathrm{G}_{\mathrm{nT}-2}+(1-\alpha)\left(\frac{\mathrm{K}_{\mathrm{T}-2}}{\mathrm{n}}\right)^{-\alpha} \mathrm{B}_{\mathrm{nT}-2} \leq \tau_{\mathrm{nT}-2}^{\mathrm{o}} \mathrm{S}_{\mathrm{nT}-3}(1-\alpha)\left(\frac{\mathrm{K}_{\mathrm{T}-2}}{\mathrm{n}}\right)^{-\alpha}+\tau_{\mathrm{nT}-2}^{\mathrm{y}} \alpha\left(\frac{\mathrm{K}_{\mathrm{T}-2}}{\mathrm{n}}\right)^{1-\alpha}+\mathrm{B}_{\mathrm{nT}-1},
\end{gathered}
$$

$\mathrm{K}_{\mathrm{T}-2}, \mathrm{~B}_{1 \mathrm{~T}-2}, \mathrm{~B}_{2 \mathrm{~T}-2}, \ldots, \mathrm{B}_{\mathrm{nT}-2}$, and $\mathrm{S}_{1 \mathrm{~T}-3}, \mathrm{~S}_{2 \mathrm{~T}-3}, \ldots, \mathrm{S}_{\mathrm{nT}-3}$ given, and where $\mathrm{K}_{\mathrm{T}-1}$ is given by (17) (with $\mathrm{t}=\mathrm{T}-2$ ).

Assuming again symmetry across countries, the conditions to be satisfied for an interior solution in T-2 are given by (20c)-(20e) and by (25a)-(25b) (with $\mathrm{t}=\mathrm{T}-2)$, thus obtaining the policy rules (26) (with $\mathrm{t}=\mathrm{T}-2$ ). Iterating this procedure $\mathrm{j}$-times and letting $\mathrm{T} \rightarrow \infty$ and $\mathrm{j} \rightarrow \infty$, one still obtains the (time-invariant) equilibrium rules (26).

\section{Cooperation among fiscal authorities caring also about long-term welfare}

To derive the unique equilibrium path of this "world" economy when there is cooperation among fiscal authorities caring also about the future generation's welfare, namely when the fiscal policy are determined by maximizing (29), suppose again that $\mathrm{T}$ is the final period of the economy. In $\mathrm{T}$ there is no future, and the equilibrium policy rules are still given by (A2). In contrast, the first-order conditions to be satisfied for a maximum in T-1 when the fiscal authorities care also about next-period social welfare are not the same as under authorities' short-termism. Indeed, the problem to be solved in T-1 when fiscal authorities caring also about future welfare cooperate is the following:

$$
\underset{\omega_{1 \mathrm{~T}-1}, \omega_{2 \mathrm{~T}-1}, \ldots, \omega_{\mathrm{nT}-1}}{\operatorname{Max}=1} \sum_{\mathrm{i}}^{\mathrm{n}} \xi \ln \left[\mathrm{S}_{\mathrm{iT}-2}\left(1-\tau_{\mathrm{iT}-1}^{\mathrm{o}}\right)(1-\alpha)\left(\frac{\mathrm{K}_{\mathrm{T}-1}}{\mathrm{n}}\right)^{-\alpha}\right]+(1-\xi) \ln \left[\frac{\left(1-\tau_{\mathrm{iT}-1}^{\mathrm{y}}\right)}{(1+\theta)} \alpha\left(\frac{\mathrm{K}_{\mathrm{T}-1}}{\mathrm{n}}\right)^{1-\alpha}\right]+\not \ln \left(\mathrm{G}_{\mathrm{iT}-1}\right)+
$$




$$
+(2-\xi) \theta\left\{\gamma \mathrm{n}\left(\frac{\gamma}{1+\gamma}\right)+(1+\gamma)(1-\alpha)\left[\ln \left(\mathrm{K}_{\mathrm{T}}\right)-\ln (\mathrm{n})\right]\right\}+\theta \mathrm{n}\left(\frac{\xi}{1+\gamma}\right)+(1-\xi) \theta \ln \left[\alpha\left(1-\tau_{\mathrm{T}}^{\mathrm{y}^{*}}\right)\right]
$$

subject to the same set of budget constraints as in (A6), $\mathrm{K}_{\mathrm{T}-1}, \mathrm{~B}_{1 \mathrm{~T}-1}, \mathrm{~B}_{2 \mathrm{~T}-1}, \ldots, \mathrm{B}_{\mathrm{nT}-1}$, and $\mathrm{S}_{1 \mathrm{~T}-2}, \mathrm{~S}_{2 \mathrm{~T}-2}, \ldots$, $\mathrm{S}_{\mathrm{nT}-2}$ given, and where $\mathrm{K}_{\mathrm{T}}$ is given by (17) (with $\mathrm{t}=\mathrm{T}-1$ ). Continuing to assume symmetry across countries $\left(\mathrm{B}_{1 \mathrm{~T}-1}=\mathrm{B}_{2 \mathrm{~T}-1}=\ldots=\mathrm{B}_{\mathrm{nT}-1}\right.$ and $\left.\mathrm{S}_{1 \mathrm{~T}-2}=\mathrm{S}_{2 \mathrm{~T}-2}=\ldots=\mathrm{S}_{\mathrm{nT}-2}\right)$, the conditions to be satisfied for an interior solution in $\mathrm{T}-1$ are given by (20c)-(20e) (with $\mathrm{t}=\mathrm{T}-1)$, and by

$$
\begin{gathered}
\frac{-(1-\xi)}{1-\tau_{\mathrm{iT}-1}^{\mathrm{y}}}+\frac{\theta(2-\xi)(1-\alpha)(1+\gamma) \mathrm{n}}{\mathrm{K}_{\mathrm{T}}} \frac{\partial \mathrm{K}_{\mathrm{T}}}{\partial \tau_{\mathrm{iT}-1}^{\mathrm{y}}}+\lambda_{\mathrm{i}} \alpha\left(\frac{\mathrm{K}_{\mathrm{T}-1}}{\mathrm{n}}\right)^{1-\alpha}=0, \mathrm{i}=1,2, \ldots, \mathrm{n}, \\
\frac{\theta(2-\xi)(1-\alpha)(1+\gamma) \mathrm{n}}{\mathrm{K}_{\mathrm{T}}} \frac{\partial \mathrm{K}_{\mathrm{T}}}{\partial \mathrm{B}_{\mathrm{iT}}}+\lambda_{\mathrm{i}}=0, \quad \mathrm{i}=1,2, \ldots, \mathrm{n} .
\end{gathered}
$$

By solving the system consisting of (20c)-(20e), (A9a) and (A9b) (and by eliminating $\lambda_{\mathrm{i}}$ ), one can obtain the policy rules that each national authority must adopt in T-1:

$$
\begin{gathered}
\tau_{\mathrm{T}-1}^{\mathrm{y}^{* * *}}=1-\frac{(1-\xi)(1+\theta)}{(1+\gamma) \alpha[1+\theta(2-\xi)(1-\alpha)]}, \\
\mathrm{B}_{\mathrm{iT}}^{* * *}=\frac{\mathrm{B}_{\mathrm{T}}^{* * *}}{\mathrm{n}}=\frac{\theta\{(1-\xi)[1-(1-\alpha)(1+\gamma)]-(1-\alpha)(1+\gamma)\}}{(1+\gamma)[1+\theta(2-\xi)(1-\alpha)]}\left(\frac{\mathrm{K}_{\mathrm{T}-1}}{\mathrm{n}}\right)^{1-\alpha}, \\
\tau_{\mathrm{T}-1}^{\mathrm{o}^{* * * *}}=1-\frac{\xi \mathrm{K}_{\mathrm{T}-1}}{(1+\gamma)(1-\alpha) \mathrm{n}\left(\frac{\left.\mathrm{K}_{\mathrm{T}-1}+\mathrm{B}_{\mathrm{T}-1}\right)[1+\theta(2-\xi)(1-\alpha)]}{\mathrm{n}},\right.} \\
\mathrm{G}_{\mathrm{T}-1}^{* * * *}=\frac{\gamma}{(1+\gamma)[1+\theta(2-\xi)(1-\alpha)]}\left(\frac{\mathrm{K}_{\mathrm{T}-1}}{\mathrm{n}}\right)^{1-\alpha},
\end{gathered}
$$

Given (17), (A10a ) and (A10b), the stock of capital evolves according to

$$
\mathrm{K}_{\mathrm{T}}^{* * *}=\frac{(2-\xi) \theta(1-\alpha) \mathrm{n}}{[1+\theta(2-\xi)(1-\alpha)]}\left(\frac{\mathrm{K}_{\mathrm{T}-1}}{\mathrm{n}}\right)^{1-\alpha}
$$

The problem to be solved in T-2 when fiscal authorities caring also about future periods' welfare cooperate is the following:

$$
\underset{\omega_{1 \mathrm{~T}-2}, \omega_{2 \mathrm{~T}-2}, \ldots, \omega_{\mathrm{nT}-2}}{\operatorname{Max}} \sum_{\mathrm{i}=1}^{\mathrm{n}} \xi \ln \left[\mathrm{S}_{\mathrm{iT}-3}\left(1-\tau_{\mathrm{iT}-2}^{\mathrm{o}}\right)(1-\alpha)\left(\frac{\mathrm{K}_{\mathrm{T}-2}}{\mathrm{n}}\right)^{-\alpha}\right]+(1-\xi) \ln \left[\frac{\left(1-\tau_{\mathrm{iT}-2}^{\mathrm{y}}\right)}{(1+\theta)} \alpha\left(\frac{\mathrm{K}_{\mathrm{T}-2}}{\mathrm{n}}\right)^{1-\alpha}\right]+\gamma \ln \left(\mathrm{G}_{\mathrm{iT}-2}\right)+
$$




$$
\begin{array}{r}
+(2-\xi) \theta\left\{\gamma \ln \left[\frac{\gamma}{(1+\gamma)[1+\theta(2-\xi)(1-\alpha)]}\right]+(1+\gamma)(1-\alpha)\left[\ln \left(\mathrm{K}_{\mathrm{T}-1}\right)-\ln (\mathrm{n})\right]\right\}+\theta \mathrm{n}\left[\frac{\xi}{(1+\gamma)[1+\theta(2-\xi)(1-\alpha)]}\right]+ \\
+(1-\xi) \theta \ln \left[\alpha\left(1-\tau_{\mathrm{T}-1}^{\mathrm{y}^{* * *}}\right)\right]+(2-\xi) \theta^{2}\left\{\gamma \ln \left(\frac{\gamma}{1+\gamma}\right)+(1+\gamma)(1-\alpha)\left[\ln \left(\mathrm{K}_{\mathrm{T}}^{* * *}\right)-\ln (\mathrm{n})\right]\right\}+\theta^{2} \ln \left(\frac{\xi}{1+\gamma}\right)+(1-\xi) \theta^{2} \ln \left[\alpha\left(1-\tau_{\mathrm{T}}^{\mathrm{y}^{*}}\right)\right]
\end{array}
$$

subject to the same set of budget constraints as in (A7), $\mathrm{K}_{\mathrm{T}-2}, \mathrm{~B}_{1 \mathrm{~T}-2}, \mathrm{~B}_{2 \mathrm{~T}-2}, \ldots, \mathrm{B}_{\mathrm{nT}-2}$, and $\mathrm{S}_{1 \mathrm{~T}-3}, \mathrm{~S}_{2 \mathrm{~T}-3}, \ldots$, $\mathrm{S}_{\mathrm{nT}-3}$ given, and where $\mathrm{K}_{\mathrm{T}-1}$ is given by (17) (with $\mathrm{t}=\mathrm{T}-2$ ). Assuming again symmetry across countries, the conditions to be satisfied for an interior solution in T-2 are given by (20c)-(20e) (with t=T-2), and by

$$
\begin{aligned}
& \frac{-(1-\xi)}{1-\tau_{\mathrm{iT}-2}^{\mathrm{y}}}+\frac{\theta(2-\xi)(1-\alpha)(1+\gamma) \mathrm{n}[1+\theta(1-\alpha)]}{\mathrm{K}_{\mathrm{T}-1}} \frac{\partial \mathrm{K}_{\mathrm{T}-1}}{\partial \tau_{\mathrm{iT}-2}^{\mathrm{y}}}+\lambda_{\mathrm{i}} \alpha\left(\frac{\mathrm{K}_{\mathrm{T}-2}}{\mathrm{n}}\right)^{1-\alpha}=0, \quad \mathrm{i}=1,2, \ldots, \mathrm{n}, \\
& \frac{\theta(2-\xi)(1-\alpha)(1+\gamma) \mathrm{n}[1+\theta(1-\alpha)]}{\mathrm{K}_{\mathrm{T}-1}} \frac{\partial \mathrm{K}_{\mathrm{T}-1}}{\partial \mathrm{B}_{\mathrm{iT}-1}}+\lambda_{\mathrm{i}}=0, \quad \mathrm{i}=1,2, \ldots, \mathrm{n} \mathrm{c} .
\end{aligned}
$$

Iterating this procedure $\mathrm{j}$-times, one can check that the conditions to be satisfied for an interior solution in $\mathrm{T}-\mathrm{j}$ are given by (20c)-(20e) (with $\mathrm{t}=\mathrm{T}-\mathrm{j})$, and by

$$
\begin{aligned}
& \frac{-(1-\xi)}{1-\tau_{\mathrm{iT}-\mathrm{j}}^{\mathrm{y}}}+\frac{\theta(2-\xi)(1-\alpha)(1+\gamma) \mathrm{n} \sum_{\mathrm{z}=0}^{\mathrm{j}-1}[\theta(1-\alpha)]^{\mathrm{z}}}{\mathrm{K}_{\mathrm{T}-\mathrm{j}+1}} \frac{\partial \mathrm{K}_{\mathrm{T}-\mathrm{j}+1}}{\partial \tau_{\mathrm{iT}-\mathrm{j}}^{\mathrm{y}}}+\lambda_{\mathrm{i}} \alpha\left(\frac{\mathrm{K}_{\mathrm{T}-\mathrm{j}}}{\mathrm{n}}\right)^{1-\alpha}=0, \quad \mathrm{i}=1,2, \ldots, \mathrm{n}, \\
& \frac{\theta(2-\xi)(1-\alpha)(1+\gamma) \mathrm{n} \sum_{\mathrm{z}=0}^{\mathrm{j}-1}[\theta(1-\alpha)]^{\mathrm{z}}}{\mathrm{K}_{\mathrm{T}-\mathrm{j}+1}} \frac{\partial \mathrm{K}_{\mathrm{T}-\mathrm{j}+1}}{\partial \mathrm{B}_{\mathrm{iT}-\mathrm{j}+1}}+\lambda_{\mathrm{i}}=0, \quad \mathrm{i}=1,2, \ldots, \mathrm{n} .
\end{aligned}
$$

Letting $\mathrm{T} \rightarrow \infty$ and $\mathrm{j} \rightarrow \infty$, (A14a) and (A14b) converge, respectively, to (30a) and to (30b), from which—-together with (20c)-(20e)—one can obtain the (time-invariant) policy rules (31). 
Elenco dei papers del Dipartimento di Economia

2000.1 A two-sector model of the effects of wage compression on unemployment and industry distribution of employment, by Luigi Bonatti

2000.2 From Kuwait to Kosovo: What have we learned? Reflections on globalization and peace, by Roberto Tamborini

2000.3 Metodo e valutazione in economia. Dall'apriorismo a Friedman, by Matteo Motterlini

2000.4 Under tertiarisation and unemployment. by Maurizio Pugno

2001.1 Growth and Monetary Rules in a Model with Competitive Labor Markets, by Luigi Bonatti.

2001.2 Profit Versus Non-Profit Firms in the Service Sector: an Analysis of the Employment and Welfare Implications, by Luigi Bonatti, Carlo Borzaga and Luigi Mittone.

2001.3 Statistical Economic Approach to Mixed Stock-Flows Dynamic Models in Macroeconomics, by Bernardo Maggi and Giuseppe Espa.

2001.4 The monetary transmission mechanism in Italy: The credit channel and a missing ring, by Riccardo Fiorentini and Roberto Tamborini.

2001.5 Vat evasion: an experimental approach, by Luigi Mittone

2001.6 Decomposability and Modularity of Economic Interactions, by Luigi Marengo, Corrado Pasquali and Marco Valente.

2001.7 Unbalanced Growth and Women's Homework, by Maurizio Pugno

2002.1 The Underground Economy and the Underdevelopment Trap, by Maria Rosaria Carillo and Maurizio Pugno.

2002.2 Interregional Income Redistribution and Convergence in a Model with Perfect Capital Mobility and Unionized Labor Markets, by Luigi Bonatti.

2002.3 Firms' bankruptcy and turnover in a macroeconomy, by Marco Bee, Giuseppe Espa and Roberto Tamborini.

2002.4 One "monetary giant" with many "fiscal dwarfs": the efficiency of macroeconomic stabilization policies in the European Monetary Union, by Roberto Tamborini.

2002.5 The Boom that never was? Latin American Loans in London 18221825, by Giorgio Fodor. 
2002.6 L'economia senza banditore di Axel Leijonhufoud: le 'forze oscure del tempo e dell'ignoranza' e la complessità del coordinamento, by Elisabetta De Antoni.

2002.7 Why is Trade between the European Union and the Transition Economies Vertical?, by Hubert Gabrisch and Maria Luigia Segnana.

2003.1 The service paradox and endogenous economic gorwth, by Maurizio Pugno.

2003.2 Mappe di probabilità di sito archeologico: un passo avanti, di Giuseppe Espa, Roberto Benedetti, Anna De Meo e Salvatore Espa.

(Probability maps of archaeological site location: one step beyond, by Giuseppe Espa, Roberto Benedetti, Anna De Meo and Salvatore Espa).

2003.3 The Long Swings in Economic Understianding, by Axel Leijonhufvud.

2003.4 Dinamica strutturale e occupazione nei servizi, di Giulia Felice.

2003.5 The Desirable Organizational Structure for Evolutionary Firms in Static Landscapes, by Nicolás Garrido.

2003.6 The Financial Markets and Wealth Effects on Consumption An Experimental Analysis, by Matteo Ploner.

2003.7 Essays on Computable Economics, Methodology and the Philosophy of Science, by Kumaraswamy Velupillai.

2003.8 Economics and the Complexity Vision: Chimerical Partners or Elysian Adventurers?, by Kumaraswamy Velupillai.

2003.9 Contratto d'area cooperativo contro il rischio sistemico di produzione in agricoltura, di Luciano Pilati e Vasco Boatto.

2003.10 Il contratto della docenza universitaria. Un problema multi-tasking, di Roberto Tamborini.

2004.1 Razionalità e motivazioni affettive: nuove idee dalla neurobiologia e psichiatria per la teoria economica? di Maurizio Pugno.

(Rationality and affective motivations: new ideas from neurobiology and psychiatry for economic theory? by Maurizio Pugno.

2004.2 The economic consequences of Mr. G. W. Bush's foreign policy. Can th US afford it? by Roberto Tamborini

2004.3 Fighting Poverty as a Worldwide Goal by Rubens Ricupero

2004.4 Commodity Prices and Debt Sustainability by Christopher L. Gilbert and Alexandra Tabova 
2004.5 A Primer on the Tools and Concepts of Computable Economics by K. Vela Velupillai

2004.6 The Unreasonable Ineffectiveness of Mathematics in Economics by Vela K. Velupillai

2004.7 Hicksian Visions and Vignettes on (Non-Linear) Trade Cycle Theories by Vela K. Velupillai

2004.8 Trade, inequality and pro-poor growth: Two perspectives, one message? By Gabriella Berloffa and Maria Luigia Segnana

2004.9 Worker involvement in entrepreneurial nonprofit organizations. Toward a new assessment of workers? Perceived satisfaction and fairness by Carlo Borzaga and Ermanno Tortia.

2004.10 A Social Contract Account for CSR as Extended Model of Corporate Governance (Part I): Rational Bargaining and Justification by Lorenzo Sacconi

2004.11 A Social Contract Account for CSR as Extended Model of Corporate Governance (Part II): Compliance, Reputation and Reciprocity by Lorenzo Sacconi

2004.12 A Fuzzy Logic and Default Reasoning Model of Social Norm and Equilibrium Selection in Games under Unforeseen Contingencies by Lorenzo Sacconi and Stefano Moretti

2004.13 The Constitution of the Not-For-Profit Organisation: Reciprocal Conformity to Morality by Gianluca Grimalda and Lorenzo Sacconi

2005.1 The happiness paradox: a formal explanation from psycho-economics by Maurizio Pugno

2005.2 Euro Bonds: in Search of Financial Spillovers by Stefano Schiavo

2005.3 On Maximum Likelihood Estimation of Operational Loss Distributions by Marco Bee

2005.4 An enclave-led model growth: the structural problem of informality persistence in Latin America by Mario Cimoli, Annalisa Primi and Maurizio Pugno

2005.5 A tree-based approach to forming strata in multipurpose business surveys, Roberto Benedetti, Giuseppe Espa and Giovanni Lafratta.

2005.6 Price Discovery in the Aluminium Market by Isabel FiguerolaFerretti and Christopher L. Gilbert. 
2005.7 How is Futures Trading Affected by the Move to a Computerized Trading System? Lessons from the LIFFE FTSE 100 Contract by Christopher L. Gilbert and Herbert A. Rijken.

2005.8 Can We Link Concessional Debt Service to Commodity Prices? By Christopher L. Gilbert and Alexandra Tabova

2005.9 On the feasibility and desirability of GDP-indexed concessional lending by Alexandra Tabova.

2005.10 Un modello finanziario di breve periodo per il settore statale italiano: l'analisi relativa al contesto pre-unione monetaria by Bernardo Maggi e Giuseppe Espa.

2005.11 Why does money matter? A structural analysis of monetary policy, credit and aggregate supply effects in Italy, Giuliana Passamani and Roberto Tamborini.

2005.12 Conformity and Reciprocity in the "Exclusion Game": an Experimental Investigation by Lorenzo Sacconi and Marco Faillo.

2005.13 The Foundations of Computable General Equilibrium Theory, by K. Vela Velupillai.

2005.14 The Impossibility of an Effective Theory of Policy in a Complex Economy, by K. Vela Velupillai.

2005.15 Morishima's Nonlinear Model of the Cycle: Simplifications and Generalizations, by K. Vela Velupillai.

2005.16 Using and Producing Ideas in Computable Endogenous Growth, by K. Vela Velupillai.

2005.17 From Planning to Mature: on the Determinants of Open Source Take Off by Stefano Comino, Fabio M. Manenti and Maria Laura Parisi.

2005.18 Capabilities, the self, and well-being: a research in psychoeconomics, by Maurizio Pugno.

2005.19 Fiscal and monetary policy, unfortunate events, and the SGP arithmetics. Evidence from a growth-gap model, by Edoardo Gaffeo, Giuliana Passamani and Roberto Tamborini

2005.20 Semiparametric Evidence on the Long-Run Effects of Inflation on Growth, by Andrea Vaona and Stefano Schiavo.

2006.1 On the role of public policies supporting Free/Open Source Software. An European perspective, by Stefano Comino, Fabio M. Manenti and Alessandro Rossi. 
2006.2 Back to Wicksell? In search of the foundations of practical monetary policy, by Roberto Tamborini

2006.3 The uses of the past, by Axel Leijonhufvud

2006.4 Worker Satisfaction and Perceived Fairness: Result of a Survey in Public, and Non-profit Organizations, by Ermanno Tortia

2006.5 Value Chain Analysis and Market Power in Commodity Processing with Application to the Cocoa and Coffee Sectors, by Christopher L. Gilbert

2006.6 Macroeconomic Fluctuations and the Firms' Rate of Growth Distribution: Evidence from UK and US Quoted Companies, by Emiliano Santoro

2006.7 Heterogeneity and Learning in Inflation Expectation Formation: An Empirical Assessment, by Damjan Pfajfar and Emiliano Santoro

2006.8 Good Law \& Economics needs suitable microeconomic models: the case against the application of standard agency models: the case against the application of standard agency models to the professions, by Lorenzo Sacconi

2006.9 Monetary policy through the "credit-cost channel". Italy and Germany, by Giuliana Passamani and Roberto Tamborini

2007.1 The Asymptotic Loss Distribution in a Fat-Tailed Factor Model of Portfolio Credit Risk, by Marco Bee

2007.2 Sraffa?s Mathematical Economics - A Constructive Interpretation, by Kumaraswamy Velupillai

2007.3 Variations on the Theme of Conning in Mathematical Economics, by Kumaraswamy Velupillai

2007.4 Norm Compliance: the Contribution of Behavioral Economics Models, by Marco Faillo and Lorenzo Sacconi

2007.5 A class of spatial econometric methods in the empirical analysis of clusters of firms in the space, by Giuseppe Arbia, Giuseppe Espa e Danny Quah.

2007.6 Rescuing the LM (and the money market) in a modern Macro course, by Roberto Tamborini.

2007.7 Family, Partnerships, and Network: Reflections on the Strategies of the Salvadori Firm of Trento, by Cinzia Lorandini.

2007.8 I Verleger serici trentino-tirolesi nei rapporti tra Nord e Sud: un approccio prosopografico, by Cinzia Lorandini. 
2007.9 A Framework for Cut-off Sampling in Business Survey Design, by Marco Bee, Roberto Benedetti e Giuseppe Espa

2007.10 Spatial Models for Flood Risk Assessment, by Marco Bee, Roberto Benedetti e Giuseppe Espa

2007.11 Inequality across cohorts of households:evidence from Italy, by Gabriella Berloffa and Paola Villa

2007.12 Cultural Relativism and Ideological Policy Makers in a Dynamic Model with Endogenous Preferences, by Luigi Bonatti

2007.13 Optimal Public Policy and Endogenous Preferences: an Application to an Economy with For-Profit and Non-Profit, by Luigi Bonatti

2007.14 Breaking the Stability Pact: Was it Predictable?, by Luigi Bonatti and Annalisa Cristini. 
PUBBLICAZIONE REGISTRATA PRESSO IL TRIBUNALE DI TRENTO 